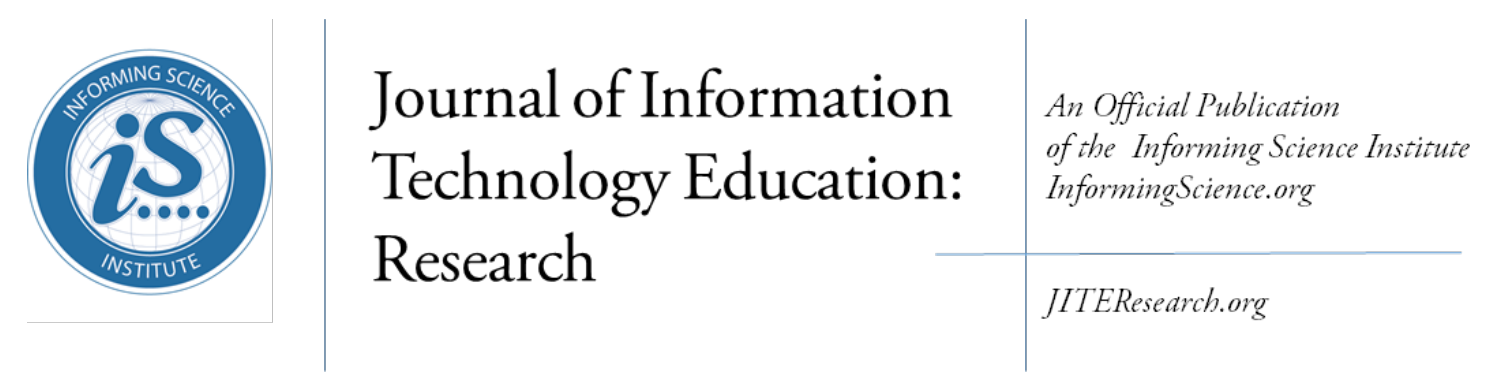

Volume 16, 2017

\title{
FACTORS AFFECTING SOCIAL NETWORK USE BY STUDENTS IN INDONESIA
}

\author{
Budhi Kristianto * Assumption University of Thailand, budhik@staff.uksw.edu \\ Bangkok, Thailand \\ * Corresponding author
}

\begin{abstract}
Background Although Indonesia is one of the world's most populated countries with a high penetration of internet usage there has been little research on SNS usage in Indonesia, especially involving children. Instead, SNS research in Indonesia has focused on university students and political, marketing, and disaster mitigation issues.

Aim/Purpose In order to address this gap a theoretical model is formulated from a review of previous studies incorporating basic constructs found in the Technology Acceptance Model (Perceived Usefulness, Perceived Ease of Use, and Attitude) as well as other influences, motivations, and individual characteristics that affect a child's attitude toward the use of SNS.

Methodology The model is evaluated and developed using data collected from 460 children in primary school grades 4, 5, and 6 in five cities in Indonesia. The statistical techniques implemented with SPSS and Amos computer software (t-tests, correlation coefficients, principal component factor analysis, Cronbach alpha coefficients, and structural equation modeling (SEM) analysis).

Findings The results confirm many of the effects on a child's attitude toward SNS reported in previous studies due to: the usefulness and ease of use of SNS; parental influence; feelings of flow experience and risk; and the child's level of access, technical expertise, and experience with SNS. New findings include significant correlations and causal effects involving: the influences of peers and parents; the child's level of technical expertise; and feelings of flow experience.

Contribution Despite limitations related to sampling and the administration of a questionnaire among young children, the findings contribute to theory as well as practice and provide guidance on effective ways to improve children's attitudes towards the use of SNS.
\end{abstract}

Keywords attitude, children, Indonesia, parental influences, peer influences, social networks, TAM

Accepted by Editors Zlatko Kovacic \& Peter Blakey | Received: October 12, 2016| Revised: February 22, 2017 | Accepted: March 5, 2017.

Cite as: Kristianto, B. (2017). Factors affecting social network use by students in Indonesia. Journal of Information Technology Education: Research, 16, 69-103. Retrieved from http://www.informingscience.org/Publications/3675

(CC BY-NC 4.0) This article is licensed it to you under a Creative Commons Attribution-NonCommercial 4.0 International License. When you copy and redistribute this paper in full or in part, you need to provide proper attribution to it to ensure that others can later locate this work (and to ensure that others do not accuse you of plagiarism). You may (and we encourage you to) adapt, remix, transform, and build upon the material for any non-commercial purposes. This license does not permit you to use this material for commercial purposes. 


\section{INTRODUCTION}

Indonesia is one of most populated countries in the world with 252.4 million citizens where 88.1 million people use the internet and 1.47 million of them are primary school students (APJII, 2015). Table 1 summarizes characteristics of the use of the internet reported by the Indonesian Internet Provider Association (APJII, 2015) using subjects from 42 cities across Indonesia. The information is consistent with that released in 2014 by the Indonesian Ministry of Communication and Information (KomInfo, 2014).

Table 1: Indonesian internet user profile 2015

\begin{tabular}{|l|r|l|r|r|r|r|c|}
\hline \multicolumn{1}{|c|}{ Occupation } & \multicolumn{1}{|c|}{$\begin{array}{c}\text { Freq } \\
\mathbf{( \% )}\end{array}$} & \multicolumn{1}{|c|}{ Activities } & $\begin{array}{c}\text { Freq } \\
\mathbf{( \% )}\end{array}$ & $\begin{array}{c}\text { Accessing } \\
\text { Device }\end{array}$ & $\begin{array}{c}\text { Freq } \\
\mathbf{( \% )}\end{array}$ & $\begin{array}{c}\text { Time } \\
\text { spent per } \\
\text { day }\end{array}$ & $\begin{array}{c}\text { Freq } \\
(\mathbf{0})\end{array}$ \\
\hline Employee & 55 & SNS & 87.4 & Smart phones & 85 & $<1$ hour & 29.6 \\
\hline Housewife & 16 & $\begin{array}{l}\text { Information } \\
\text { seeking }\end{array}$ & 68.7 & Laptops & 32 & $1-3$ hours & 37.7 \\
\hline University student & 18 & $\begin{array}{l}\text { Instant mes- } \\
\text { saging }\end{array}$ & 59.9 & Desktops & 14 & $3-5$ hours & 17.6 \\
\hline $\begin{array}{l}\text { Primary, secondary, } \\
\text { high school student }\end{array}$ & 5 & News update & 59.7 & Tablets & 13 & $>5$ hours & 15.1 \\
\hline Unspecified & 6 & - & - & - & - & - \\
\hline
\end{tabular}

From Table 1 it is seen that in Indonesia the internet is used more often for Social Network Sites/Systems (SNS) activities than any of the other activities. It is estimated that there are approximately 1.28 million primary school children using popular SNS such as Facebook, Twitter, Instagram, Blackberry Messenger, Line, Youtube, and Whatsapp (TechInAsia, 2016). Anecdotal information from teachers indicates that primary school children use smart phones extensively out of school hours and that normally students are not allowed to bring smart phones to school. Also, many children have their own SNS accounts even though providers such as Facebook do not allow visitors below 13 years of age to register. Lwin, Miyazaki, Stanaland, and Lee (2012) state that children go online for three main reasons: entertainment, socializing, and information seeking. There are several motivations to investigate the factors that influence children's attitudes towards SNS. Children make up a significant part of the Indonesian population and it is important to understand what motivates their use of SNS especially considering that they are young, they are informed by SNS, and they will play an important role determining the future direction and use of SNS. Apart from descriptive studies focused on demographic information about children's use of SNS in Indonesia (e.g. APJII, 2015; KomInfo, 2014) there have been only a few studies focused on university students, and political, marketing, and disaster mitigation issues (Ai, Comfort, Dong, \& Znati, 2015; Erlin, Fitri, \& Susandri, 2015; Gazali, 2014; Guarnacci, 2016; Lim, 2013; Maharani \& Gozali, 2015). However, there do not appear to be any studies that examine the factors that influence children's attitudes towards the use of SNS. Although there may be practical reasons for this lack of research focused on children associated with the problems of accessing children and data collection, it is encouraging that Lee (2015) reports that nine year olds are able to completely understand how to fill out complex questionnaires, read and write complex sentences, and expresses complex ideas. Also, it is important to study children's attitudes towards SNS because of the possibility of understanding influences on children by peers and parents, implementing SNS functions and activities focused positively on children's social and educational needs, and introducing children responsibly to their roles as future or present SNS users in social commerce activities. 
Social media systems are defined as internet-based tools and platforms that facilitate the sharing of information including the transfer of text, photos, audio video, and information in general (Bassell, 2010). SNS are closely related systems, which are defined as a set of social entities that include people and organizations that are connected by a set of socially meaningful relationships and who interact with each other in sharing values (Kwon \& Wen, 2010). A SNS offers a platform for online users to interact with one another and manage their friendships (Ku, Chen, \& Zhang, 2013). SNS create a member-based online community where a user usually begins by posting basic personal information and then communicates with other members in a variety of ways and on a variety of topics. In addition, SNS provide users with entertainment opportunities such as watching videos, listening to music, playing online games, and browsing the daily news (J. Wang, Jackson, Gaskin, \& Wang, 2014).

SNS adoption research has mainly used the Technology Acceptance Model (TAM) (Davis, Bagozzi, \& Warshaw, 1989) as the basic theory. Some studies have used the Theory of Reasoned Action (TRA), the Theory of Planned Behavior (TPB), or Expectation-Confirmation Theory (ECT) especially for studying the continuance use of SNS. However, TAM was formulated by enhancement of TRA and TPB, and ECT uses the perceived usefulness construct of TAM as its main component (Al-Debei, Al-Lozi, \& Papazafeiropoulou, 2013; Chang \& Zhu, 2012). Consequently, the three core constructs of TAM (perceived usefulness, perceived ease of use, and attitude) were used in the theoretical model for this study complemented by external factors derived from previous studies that reflect possible influences on the attitudes of children towards SNS (e.g., feelings of flow experience and risk, the child's technical expertise and level of access to and experience with SNS) (Barbovschi, Macháčková, \& Ólafsson, 2015; Clifton, Goodall, Ban, \& Birks, 2013; De-Miguel-Molina, OltraGutiérrez, \& Sarabdeen, 2010; Hamm et al., 2014; Hsiao, 2011).

Against this background, the study addresses four questions:

(a) What factors influence the attitudes of primary school aged students to the use of SNS in the context of Indonesia?

(b) What are the relationships among the factors in the first question?

(c) Which of the relationships in the second question represent significant causal effects?

(d) What are the theoretical and practical implications of the answers to the preceding three questions?

The findings are expected to contribute to an improved theoretical understanding of the factors that influence children's attitude toward the use of SNS, especially in the context of Indonesia. In addition, the findings are expected to provide practical insights as to how children's attitudes to the use of SNS may be improved. The findings are of particular interest to those involved in the social and educational development of children at present and in a future where it is expected that SNS will play an increasingly important role in the lives and development of children.

This article is structured into the following sections: the research design and methodology; a review of related literature; measurement of variables; data preparation and preliminary analysis; model analysis and development; discussion of the findings; and conclusion.

\section{RESEARCH DESIGN AND METHODOLOGY}

This study examines cross-sectional data using quantitative techniques in order to develop theoretical knowledge with practical implications. The subject of the study is a child who is in grade 4, 5, or 6 in an urban primary school in Indonesia and who uses SNS. Assuming that 60 percent of the 1.28 million primary school children in Indonesia are in schools in urban areas and that 50 percent of these students are in grades 4,5 , and 6 , the size of this target population was estimated to be approximately 0.4 million. Using a 5 percent level of precision with a 95 percent confidence interval the minimum sample size for the study was determined to be 400 (Israel, 2013). Also, this minimum sample size satisfied the criteria for the statistical validity of the statistical techniques implemented with SPSS and Amos computer software (t-tests, correlation coefficients, principal component factor analysis, Cronbach alpha coefficients, and structural equation modeling (SEM) analysis). 
Using the existing measuring instruments identified in Table 5, a self-administered questionnaire was prepared in the English language, translated into Bahasa Indonesia, and reviewed and modified by an expert group of three primary school teachers. The Bahasa Indonesia version was then used in a pilot study with five children from the target population. No further modifications were necessary and the Bahasa Indonesia language version was used in the full study. An abbreviated notated English language version of the questionnaire is in Appendix A.

There was no satisfactory sampling frame available for this target population and so following the advice from Neuman (2006) a purposive sampling method was used. The researcher made use of direct personal contacts with primary school teachers from three different schools in each of five cities in Indonesia (Semarang, Solo, Boyolali, Klaten, and Jakarta). In each of these 15 schools it was decided to obtain a sample of 45 students (15 in each of the grades 4, 5, and 6) giving a total sample of 675 students. The study questionnaire was distributed to the teachers with clear instructions about the study and the questions as well as the strong need for the teacher to present the questions to the students with explanations and guidance. In each case the questionnaire was completed by students in class with a teacher or the researcher who supervised the completion of the questionnaires explaining the questions and answering any questions from the students. The report by Lee (2015) that children in these primary school grades are able to complete complex questionnaires was encouraging, and it was expected that, with the direct supervision provided by the researcher and teachers, the responses would be valid and reliable. As planned, 675 questionnaires were returned but 147 were found to contain a missing response for at least one of the questions and these were removed from the sample leaving 528 completed questionnaires in the final sample, which satisfied the minimum sample size of 400 determined for the study.

\section{REVIEW OF RELATEd LiTERATURE AND THE THEORETICAL MODEL}

The review begins with an overview of previous related studies. This is followed by a discussion of the important constructs and the relations among those constructs derived from previous studies, which form the structure of the theoretical model for the study, and the set of research hypothesis associated with the theoretical model.

\section{AN OVERVIEW OF PREVIOUS STUDIES}

In Table 2 previous studies are described in relation to three key characteristics (focus of the study, research approach, and data collection method). The studies are organized in categories representing nine themes among the studies (children, attitude toward use of technology, social media, flow experience, perceived enjoyment, perceived influence, technology self-efficacy, technology accessibility, and risk).

Table 2: Overview of previous studies

\begin{tabular}{|l|l|l|l|}
\hline \multicolumn{1}{|c|}{ Focus of the Study } & \multicolumn{1}{|c|}{$\begin{array}{c}\text { Research } \\
\text { Approach }\end{array}$} & $\begin{array}{l}\text { Data Collec- } \\
\text { tion Method }\end{array}$ & References \\
\hline \multicolumn{2}{|c|}{ Children } \\
\hline $\begin{array}{l}\text { Investigation of the children social network and their social } \\
\text { circle }\end{array}$ & $\begin{array}{l}\text { Exploratory } \\
\text { Qualitative study }\end{array}$ & $\begin{array}{l}\text { Interview, Con- } \\
\text { tent Analysis }\end{array}$ & Lewis (2005) \\
\hline \multicolumn{2}{|c|}{ Attitude Toward Use of Technology } & Davis (1989) \\
\hline $\begin{array}{l}\text { Validation of perceived usefulness and perceived ease of use } \\
\text { as fundamental determinants of user acceptance }\end{array}$ & $\begin{array}{l}\text { Explanatory } \\
\text { Quantitative } \\
\text { study }\end{array}$ & Questionnaire & Dongitudinal \\
Prediction of user acceptance to measure user intension & Qudy & $\begin{array}{l}\text { Davis et al. } \\
(1989)\end{array}$ \\
\hline
\end{tabular}




\begin{tabular}{|c|c|c|c|}
\hline \multicolumn{4}{|l|}{ Social Media } \\
\hline $\begin{array}{l}\text { Empirical detection of certain engagement factors and their } \\
\text { potentials to build and increase online communities around } \\
\text { brands and products }\end{array}$ & $\begin{array}{l}\text { Experimental } \\
\text { study }\end{array}$ & $\begin{array}{l}\text { Observations } \\
\text { and experiments }\end{array}$ & $\begin{array}{l}\text { Predrag } \\
(2014)\end{array}$ \\
\hline $\begin{array}{l}\text { Investigation of SNS experience as dominant predictor of } \\
\text { social game accessibility }\end{array}$ & $\begin{array}{l}\text { Explanatory } \\
\text { Quantitative } \\
\text { study }\end{array}$ & Questionnaire & $\begin{array}{l}\text { Park \& Lee } \\
(2012)\end{array}$ \\
\hline \multicolumn{4}{|c|}{ Flow Experience } \\
\hline $\begin{array}{l}\text { Examination the flow experience in continuance intension of } \\
\text { use }\end{array}$ & $\begin{array}{l}\text { Explanatory } \\
\text { Quantitative } \\
\text { study }\end{array}$ & Questionnaire & $\begin{array}{l}\text { Gao \& Bai } \\
(2014)\end{array}$ \\
\hline \multicolumn{4}{|c|}{ Perceived Enjoyment } \\
\hline Determination of hedonic motivation for SNS use & $\begin{array}{l}\text { Explanatory } \\
\text { Quantitative } \\
\text { study }\end{array}$ & Questionnaire & $\begin{array}{l}\text { Ernst, } \\
\text { Pfeiffer, \& } \\
\text { Rothlauf } \\
(2013)\end{array}$ \\
\hline $\begin{array}{l}\text { Investigation of the role of adults during children's (aged 5-6) } \\
\text { computer use, why and how children use computer, and what } \\
\text { are children behavior during computer use }\end{array}$ & $\begin{array}{l}\text { Exploratory } \\
\text { study }\end{array}$ & $\begin{array}{l}\text { Interview and } \\
\text { observations }\end{array}$ & $\begin{array}{l}\text { Karuppiah } \\
(2014)\end{array}$ \\
\hline \multicolumn{4}{|c|}{ Perceived Influence } \\
\hline Examination of parenting dimension for internet use & $\begin{array}{l}\text { Explanatory } \\
\text { Quantitative } \\
\text { study }\end{array}$ & Questionnaire & $\begin{array}{l}\text { Alvarez, To- } \\
\text { rres, Rodri- } \\
\text { gues, Padilla, } \\
\text { \& Rodrigo } \\
(2013)\end{array}$ \\
\hline $\begin{array}{l}\text { Investigation of the role of adults during children's (aged 5-6) } \\
\text { computer use, why and how children use computer, and what } \\
\text { are children behavior during computer use }\end{array}$ & $\begin{array}{l}\text { Exploratory } \\
\text { study }\end{array}$ & $\begin{array}{l}\text { Interview and } \\
\text { observations }\end{array}$ & $\begin{array}{l}\text { Karuppiah } \\
(2014)\end{array}$ \\
\hline \multicolumn{4}{|c|}{ Technology Self-efficacy } \\
\hline $\begin{array}{l}\text { Examination of the computer self-efficacy as predictor of } \\
\text { perceive usefulness and perceive ease of use in behavioral in- } \\
\text { tension of use }\end{array}$ & $\begin{array}{l}\text { Explanatory } \\
\text { Quantitative } \\
\text { study }\end{array}$ & Questionnaire & $\begin{array}{l}\text { Hong, } \\
\text { Hwang, } \\
\text { Ting, Tai, \& } \\
\text { Lee (2013) }\end{array}$ \\
\hline $\begin{array}{l}\text { Comparison of the Theory of Reasoned Action and Technol- } \\
\text { ogy Acceptance Model }\end{array}$ & $\begin{array}{l}\text { Longitudinal } \\
\text { study }\end{array}$ & Questionnaire & $\begin{array}{l}\text { Davis et al. } \\
(1989)\end{array}$ \\
\hline \multicolumn{4}{|c|}{ Technology Accessibility } \\
\hline $\begin{array}{l}\text { Investigation of relationship between distinct media user types } \\
\text { and social displacement among children under the age of } 13\end{array}$ & $\begin{array}{l}\text { Explanatory } \\
\text { Quantitative } \\
\text { study }\end{array}$ & Questionnaire & \begin{tabular}{|l} 
Endestad, \\
Heim, Kaare, \\
Torgersen, \& \\
Brandtzaeg \\
$(2011)$
\end{tabular} \\
\hline \multicolumn{4}{|l|}{ Risk } \\
\hline $\begin{array}{l}\text { Examination of particular online service towards risk incre- } \\
\text { ment of internet usage among children aged } 9-16\end{array}$ & $\begin{array}{l}\text { Explanatory } \\
\text { Quantitative } \\
\text { study }\end{array}$ & Questionnaire & $\begin{array}{l}\text { Staksrud, } \\
\text { Olafsson, \& } \\
\text { Livingstone } \\
(2013)\end{array}$ \\
\hline $\begin{array}{l}\text { Examination of motivations of young consumer's internet use } \\
\text { (aged 10-12) and their influence to privacy concerns }\end{array}$ & $\begin{array}{l}\text { Explanatory } \\
\text { Quantitative } \\
\text { study }\end{array}$ & Questionnaire & $\begin{array}{l}\text { Lwin et al. } \\
(2012)\end{array}$ \\
\hline $\begin{array}{l}\text { Examination of how children learn and interpret risky dimen- } \\
\text { sions of SNS }\end{array}$ & $\begin{array}{l}\text { Exploratory } \\
\text { study }\end{array}$ & Interview & $\begin{array}{l}\text { Livingstone } \\
(2014)\end{array}$ \\
\hline
\end{tabular}


The studies in Table 2 used mainly quantitative methods for analysis, were explanatory in nature, and collected data from subjects using a questionnaire. These characteristics are the same as for this study. From Table 2 it is seen that researchers have investigated many aspects of SNS including psychological, sociological, educational, cultural, communicational, health, and economical aspects (Barbovschi et al., 2015; Clifton et al., 2013; De-Miguel-Molina et al., 2010; Hamm et al., 2014; Hsiao, 2011). Most of the SNS adoption studies used the TAM as their basic theory. The Theory of Reasoned Action (TRA), the Theory of Planned Behavior (TPB), and Expectation-Confirmation Theory (ECT) have been used less often but they are closely related to TAM, which was formulated by modifying TRA and TPB, while ECT uses the TAM construct of perceived usefulness as a key factor (Al-Debei et al., 2013; Chang \& Zhu, 2012). TAM has been evaluated and used in many contexts with samples drawn from various populations over a long period of time and has proven to be appropriate for technology acceptance research including SNS. Consequently, TAM was used as the core of the theoretical model in this study.

Apart from the three basic TAM constructs (perceived usefulness, perceived ease of use, and attitude) the studies in Table 2 suggested the inclusion of other constructs associated with the nine themes presented in Table 2 and specifically reflecting the nature of SNS, characteristics of children, and influences on children. Discussion of all of the constructs and their relationships included in the theoretical model for this study are presented next.

\section{IMPORTANT CONSTRUCTS AND RELATIONSHIPS}

Three basic components (attitude toward use of technology, perceived usefulness, and perceived ease of use) from the TAM proposed by Davis (1989) were evident in previous studies as being important constructs. Attitude toward use of technology is a psychological construct that refers to the extent to which a user feels encouraged to use the technology (Ajzen, 1991) and perceptions of the amount of effort needed to use the technology (perceived ease of use) and the extent to which the technology fulfills a purpose for the user (perceived usefulness) are considered to be important determinants of attitude towards the technology. Although the TAM is commonly used in research involving adults, it has been used in studies involving children. Nowadays children start to use technology at an early age and, although there are obvious differences in cognitive, affective, and psychomotor growth between adults and children, the investigation of the relevance of TAM constructs in studies of technology adoption by children is an important matter.

A child is surrounded by an inner circle of relationships involving parents, siblings, and peers, and this inner circle has an important influence on a child (Lewis, 2005). Consequently, perceived parent influence and perceived peer influence are included as important constructs in the study with direct and indirect influences on the child's attitude toward use of the technology. Primary school grade 4, 5 , and 6 children are heavily reliant on their parents, especially in relation to support and resources and facilities that they use. Consequently, the construct technology accessibility (i.e., the extent to which a child believes that a technology is readily available to them) is included in the study as a determinant of attitude toward use of the technology. Children go online for three main reasons: entertainment, socializing, and information seeking (Lwin et al., 2012). When children use services such as social games, they feel enjoyment which has an effect on the extent to which they feel the technology is useful to them. This enjoyment is influenced by flow experience (i.e., a holistic experience felt when individuals act with total involvement). Outside home, children gain experience using technology at school or as they play with their friends, and this experience enhances their capabilities to use technologies (i.e., their technology self-efficacy). This capability has an influence on their perceptions of the ease of using the technology and its usefulness.

Risk involves exposure to a dangerous situation. An increase in risk awareness with respect to internet use among children confirmed that preteen age children were aware of risks of personal information disclosure, system security, data stealing, and contact with strangers (Livingstone, 2014; Lwin et al., 2012; W. Shin \& Ismail, 2014; Staksrud et al., 2013). Based on these studies, risk is seen as an 
important construct in the study affected by the influences of parents and peers and having an important effect on the child's attitude to the use of technology.

Table 3 presents a referenced operational definition for each of the important constructs derived from the related literature.

Table 3: Definitions of constructs

\begin{tabular}{|c|c|c|}
\hline Constructs & Definition & Reference \\
\hline Flow Experience & $\begin{array}{l}\text { The extent to which an individual has the holistic experience that peo- } \\
\text { ple feel when they act with total involvement. }\end{array}$ & Gao \& Bai (2014) \\
\hline $\begin{array}{l}\text { Technology Self- } \\
\text { Efficacy }\end{array}$ & $\begin{array}{l}\text { The extent to which an individual believes that they have the capability } \\
\text { to perform a task. }\end{array}$ & Hong et al. (2013) \\
\hline $\begin{array}{l}\text { Perceived Ease of } \\
\text { Use }\end{array}$ & $\begin{array}{l}\text { The degree to which the individual expects the system to be free of } \\
\text { effort. }\end{array}$ & Davis et al. (1989) \\
\hline $\begin{array}{l}\text { Perceived Enjoy- } \\
\text { ment }\end{array}$ & $\begin{array}{l}\text { The extent to which an individual experiences pleasure and enjoyment } \\
\text { associated with the using the system. }\end{array}$ & $\begin{array}{l}\text { Praveena \& } \\
\text { Thomas (2013) }\end{array}$ \\
\hline $\begin{array}{l}\text { Perceived Peer In- } \\
\text { fluence }\end{array}$ & $\begin{array}{l}\text { The extent to which the opinions of external socializing agents are } \\
\text { important to the individual. }\end{array}$ & $\begin{array}{l}\text { W. Shin \& Ismail } \\
(2014)\end{array}$ \\
\hline $\begin{array}{l}\text { Perceived Parent } \\
\text { Influence }\end{array}$ & $\begin{array}{l}\text { The extent to which interpersonal interactions between parents and a } \\
\text { child influence the child's use of the system. }\end{array}$ & $\begin{array}{l}\text { W. Shin \& Ismail } \\
(2014)\end{array}$ \\
\hline Risk & $\begin{array}{l}\text { The extent to which an individual feels that using the system exposes } \\
\text { them to a dangerous situation. }\end{array}$ & $\begin{array}{l}\text { YourDictionary } \\
(2015)\end{array}$ \\
\hline $\begin{array}{l}\text { Perceived Useful- } \\
\text { ness }\end{array}$ & $\begin{array}{l}\text { The user's perception as to how useful the system is for achieving their } \\
\text { purpose for using the system. }\end{array}$ & Davis et al. (1989) \\
\hline $\begin{array}{l}\text { Technology Acces- } \\
\text { sibility }\end{array}$ & $\begin{array}{l}\text { The extent to which the individual believes that the system is readily } \\
\text { available and is either free or relatively inexpensive. }\end{array}$ & Zhang (2010) \\
\hline $\begin{array}{l}\text { Technology Expe- } \\
\text { rience }\end{array}$ & $\begin{array}{l}\text { The amount of knowledge or skills the individual has related to the use } \\
\text { of the system }\end{array}$ & $\begin{array}{l}\text { Shen, Cheung, } \\
\text { Lee, \& Chen } \\
(2011)\end{array}$ \\
\hline $\begin{array}{l}\text { Attitude toward } \\
\text { Use of Technology }\end{array}$ & $\begin{array}{l}\text { The extent to which an individual has a favorable evaluation or ap- } \\
\text { praisal of the system. }\end{array}$ & Ajzen (1991) \\
\hline
\end{tabular}

\section{THEORETICAL MODEL AND RESEARCH HYPOTHESIS}

Based on the extraction of the studies reviewed in the previous section, a theoretical model is developed. The constructs in Table 3 and the relationships among them form the structure of the theoretical model shown in Figure 1, which is notated to identify the 15 research hypothesis (H1 - H15) that are stated specifically in Table 4. 


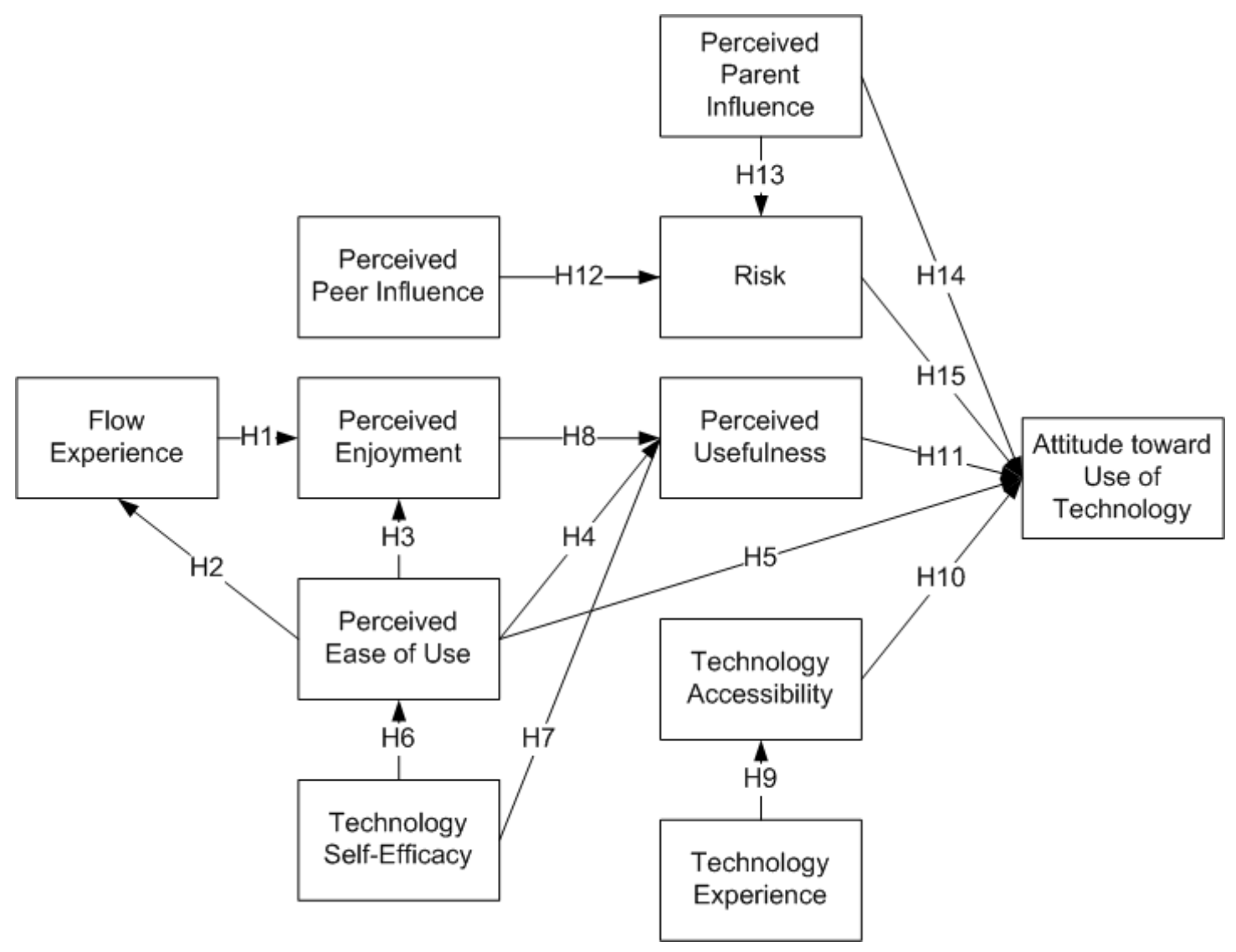

Figure 1: Theoretical model.

Table 4: Research hypothesis

\begin{tabular}{|c|c|c|}
\hline \multicolumn{2}{|r|}{ Hypothesis } & \multirow{2}{*}{\begin{tabular}{|l}
\multicolumn{1}{c}{ Reference } \\
Gao \& Bai (2014), \\
Chang \& Zhu \\
$(2012)$
\end{tabular}} \\
\hline H1 & Flow Experience has a significant positive direct effect on Perceived Enjoyment & \\
\hline $\mathrm{H} 2$ & Perceived Ease of Use has a significant positive direct effect on Flow Experience & Hsu \& Lu (2004) \\
\hline H3 & Perceived Ease of Use has a significant positive direct effect on Perceived Enjoyment & Ernst et al. (2013) \\
\hline $\mathrm{H} 4$ & Perceived Ease of Use has a significant positive direct effect on Perceived Usefulness & Davis et al. (1989) \\
\hline H5 & $\begin{array}{l}\text { Perceived Ease of Use has a significant positive direct effect on Attitude toward Use } \\
\text { of Technology }\end{array}$ & Davis et al. (1989) \\
\hline H6 & $\begin{array}{l}\text { Technology Self-Efficacy has a significant positive direct effect on Perceived Ease of } \\
\text { Use }\end{array}$ & Hong et al. (2013) \\
\hline H7 & $\begin{array}{l}\text { Technology Self-Efficacy has a significant positive direct effect on Perceived Useful- } \\
\text { ness }\end{array}$ & Hong et al. (2013) \\
\hline $\mathrm{H} 8$ & Perceived Enjoyment has a significant positive direct effect on Perceived Usefulness & Ernst et al. (2013) \\
\hline H9 & $\begin{array}{l}\text { Technology Experience has a significant positive direct effect on Technology Acces- } \\
\text { sibility }\end{array}$ & Park \& Lee (2012) \\
\hline
\end{tabular}




\begin{tabular}{|l|l|l|}
\hline \multicolumn{1}{|c|}{ Hypothesis } & \multicolumn{1}{|c|}{ Reference } \\
\hline H10 & $\begin{array}{l}\text { Technology Accessibility has a significant positive direct effect on Attitude toward } \\
\text { Use of Technology } \\
\text { Technology }\end{array}$ & Zhang (2010) \\
\hline H12 & $\begin{array}{l}\text { Perceived Peer Influence has a significant negative direct effect on Risk } \\
\text { H13 }\end{array}$ & $\begin{array}{l}\text { Perceived Phin \& Ismail } \\
(2014)\end{array}$ \\
\hline H14 & $\begin{array}{l}\text { Perceived Parent Influence has a significant negative direct effect on Attitude toward } \\
\text { Use of Technology }\end{array}$ & $\begin{array}{l}\text { W. Shin \& Ismail } \\
(2014), \\
\text { Karuppiah (2014) } \\
(2014), \\
\text { Karuppiah (2014) }\end{array}$ \\
\hline H15 & Risk has a significant negative direct effect on Attitude toward Use of Technology & $\begin{array}{l}\text { (2011), } \\
\text { Renny, Guritno, \& } \\
\text { Siringoringo (2013) }\end{array}$ \\
\hline
\end{tabular}

\section{MEASUREMENT OF VARIABLES}

The notated questionnaire in Appendix A shows the labels used for variables and indicators as well as the measurement scales used for all of the variables. Table 5 shows the details of the measurement of each of the 11 latent variables included in the theoretical model in Figure 1 with references to existing measuring instruments that were used to develop the study questionnaire.

Table 5: Measurements of model variables

\begin{tabular}{|l|l|l|}
\hline \multicolumn{1}{|c|}{ Latent Model Variable (Symbol) } & Indicators & \multicolumn{1}{|c|}{ Existing Measuring Instrument } \\
\hline Flow Experience (FE) & FE1 - 3 & Chang \& Zhu (2012), Gao \& Bai (2014) \\
\hline Technology Self-Efficacy (TSE) & TSE1 - 3 & Hong et al. (2013) \\
\hline Perceived Ease of Use (PEU) & PEU1 - 3 & Hsu \& Lu (2004) \\
\hline Perceived Enjoyment (PE) & PE1 - 3 & Ernst et al. (2013) \\
\hline Perceived Peer Influence (PPeI) & PPeI1 - 3 & W. Shin \& Ismail (2014), Youn (2008) \\
\hline Perceived Parent Influence (PPaI) & PPaI1 - 3 & W. Shin \& Ismail (2014), Youn (2008) \\
\hline Risk (R) & R1 - 3 & Renny et al. (2013) \\
\hline Perceived Usefulness (PU) & PU1 - 3 & Ernst et al. (2013) \\
\hline Technology Accessibility (TA) & TA1 - 3 & Park \& Lee (2012) \\
\hline Technology Experience (TE) & TE1 - 3 & $\begin{array}{l}\text { Park \& Lee (2012), Pruet, Ang, \& Farzin } \\
(2014)\end{array}$ \\
\hline Attitude toward Use of Technology (AUT) & AUT1 - 3 & Park \& Lee (2012), D. Shin \& Shin (2011) \\
\hline
\end{tabular}

All of the indicators for the latent variables in Table 5 were measured on 5-point Likert scales and for analysis the measures were treated as interval scale measures.

\section{DATA PREPARATION AND PRELIMINARY ANALYSIS}

This section presents the results of the procedures used to prepare the data collected by the questionnaire and to conduct preliminary descriptive analysis of the prepared data. 


\section{Data preparation}

A sample of 528 questionnaires was obtained from subjects with no missing values for any of the questions. Data was entered into an SPSS worksheet. Fifty three (10 percent) questionnaires were selected at random and the accuracy of the data entry for each of those questionnaires was checked. No errors were found. Sixty eight questionnaires were found to include at least one outlier value for a model variable (i.e., a value which differs from the mean value by three or more standard deviations). These questionnaires were removed from the sample to give a final sample size of 460 , which satisfied the minimum sample size of 400 for the study.

Principal Component factor analysis was used to test the construct validity of the measures of the 11 latent model variables. In the process of determining the construct validity it was found that the three indicators PE1, PE2, and PE3 for Perceived Enjoyment each loaded significantly onto the latent variable Attitude toward Use of Technology with three indicators AUT1, AUT2, and AUT3. This is a common result, which has been described by Davis, Bagozzi, and Warshaw (1992). Consequently, the variable Perceived Enjoyment was removed from the theoretical model because its indicators actually measured Attitude toward Use of Technology. As shown in Table A1 all of the other indicators displayed satisfactory construct validity. The equivalence reliability of the valid indicators from the final factor analysis was examined using Cronbach alpha coefficients. The results in Table A1 indicate satisfactory equivalence reliability.

As a result of data preparation the theoretical model (Figure 1) was modified by the deletion of the variable Perceived Enjoyment and the deletion of the three research hypothesis in Table 4 (H1, H3, and H8), which involved the variable Perceived Enjoyment. The modified theoretical model is displayed in Figure 2.

\section{Preliminary analysis}

Analysis of the responses to questions in section 1 of the questionnaire (Appendix A) using SPSS software revealed the following characteristics for the respondents:

There are approximately equal proportions of males and females;

Their average age is 11 years with a standard deviation of 1 year;

The most popular SNS is Blackberry Messenger (43 percent) followed by Facebook and Youtube (20 percent each) while others mentioned online games, Instagram, and Google;

Most children are using SNS for 1-2 hours per day (57 percent) while much smaller proportions (2-3 percent) are using SNS for more than 6 hours per day. The average number of hours spent each day using SNS is 2.7 hours.

Overall, the sample reflects the characteristics of the target population determined for the study and the subjects have the characteristics required to provide valid and reliable answers to the items in the study questionnaire.

Table A2 displays descriptive statistics for the model variables. In addition to considering each of the indicators for a latent variable, each latent variable was reduced to a single interval scale variable with values computed for each respondent as the mean of the values assigned to its indicators. This meant that for a latent variable its indicators were each assigned and equal weight of $1 /$ (the number of indicators), which was justified by noting that the standard deviations for each of its indicators were approximately equal. For example, for Perceived Ease of Use from Table A2 the standard deviations of the indicators PEU2 and PEU3 are both 0.78 and for PEU1 the standard deviation is 0.77 . So for each respondent a single interval scale measure for Perceived Ease of Use was computed as (PEU1 + PEU2 + PEU3)/3. These single interval scale measures of the latent variables are used in the descriptive analysis presented in this section but the full set of separate measures of the indicators for latent variables are used in the SEM analysis of models. From Table A2 it is seen that the magnitudes 
of the values for skewness and kurtosis are within the limits of 3 and 7, respectively and this justifies the use of maximum likelihood estimation in subsequent SEM analysis.

T-tests were used to compare the means of the model variables for males and females. There are relatively few significant differences between males and females. However, when there is a statistically significant difference $(p<0.05)$ between the means it is seen that compared to the females the males have a greater amount of knowledge and skills needed to use SNS (Technology Experience) and they consider that SNS are easier to use (Perceived Ease of Use). On the other hand, compared to males the females feel that it is more likely that using SNS exposes them to a dangerous situation.

Table A3 displays correlation coefficients for the model variables. From Table A3 it is seen that:

Among the correlation coefficients associated with the 13 causal effects in the modified theoretical model (Figure 2) all of the correlations have a direction that is compatible with the direction of the causal effect, 12 are statistically significant at a level of 0.05 or less, but the correlation associated with the effect of Perceived Peer Influence on Risk is not statistically significant at a level of 0.05 or less. However, statistically significant correlations do not guarantee statistically significant causal effects so this result is only noted here;

From the statistically significant correlations that are not associated with causal effects in the modified theoretical model some additional plausible causal effects are suggested. These may be considered for addition to the model as part of model analysis and development. These possible additional effects are three positive direct effects of Flow Experience, Technology Experience, and Technology Self-Efficacy on Attitude toward Use of Technology.

\section{MODEL ANALYSIS AND DEVELOPMENT}

Figure 2 shows the results of the SEM analysis of the modified theoretical model using Amos software.

In Figure 2 and throughout this section the following notation is used for all effects: (a) First, the unstandardized effect is shown followed by the symbol *, ** or *** if the effect is statistically significant at a level of $0.05,0.01$, or 0.001 , respectively, and NS indicates that the unstandardized effect is not statistically significant at a level of 0.05 or less; (b) Next, in parentheses the standardized effect is shown with $\mathrm{S}, \mathrm{M}$, or $\mathrm{L}$ to indicate that the magnitude of the effect is small, medium, or large, respectively, where the magnitude of a small effect is from 0 to less than 0.1 , medium effect is from 0.1 to less than 0.5, and a large effect is at least 0.5 (Cohen, 1988).

In Figure 2 there are three causal effects highlighted that are small and not statistically significant at a level of level of 0.05 or less (Perceived Parent Influence $\rightarrow$ Attitude toward Use of Technology, Perceived Peer Influence $\rightarrow$ Risk, and Technology Self-Efficacy $\rightarrow$ Perceived Usefulness). All of the other direct effects are statistically significant at a level of 0.01 or less and they are medium in magnitude with one large effect. 


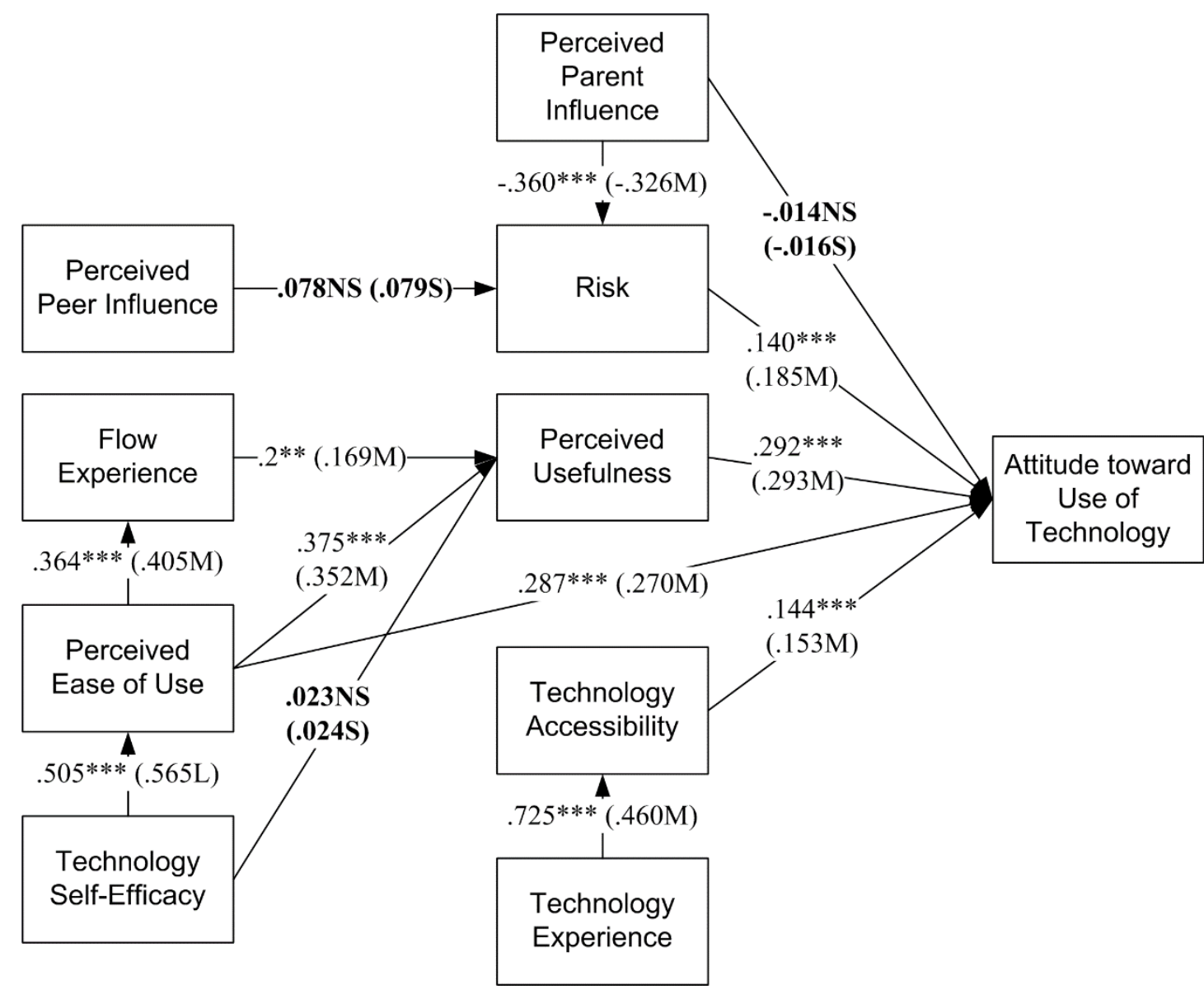

Figure 2: SEM analysis of the modified theoretical model

Table 6 presents the values of the range of fit statistics recommended by Kline (2005) for the purpose of evaluating causal models. Appendix B includes notes on these fit statistics and the interpretation of their values.

Table 6: Fit statistics for the modified theoretical model

\begin{tabular}{|c|c|r|r|r|r|r|r|r|}
\hline $\mathbf{N}$ & NC $\left(\chi^{2} / \mathbf{d f}\right)$ & RMR & GFI & AGFI & NFI & IFI & CFI & RMSEA \\
\hline \multirow{2}{*}{460} & $785.817 / 386=2.036$ & .085 & .899 & .879 & 0.918 & 0.956 & 0.961 & 0.048 \\
\cline { 2 - 6 } & \multicolumn{7}{|c|}{$\mathbf{R}^{2}$ : PEU (.329), FE (.164), TA (.211), PU (.212), R (.096), and AUT (.300) } \\
\hline
\end{tabular}

Notes: (a) Notes and interpretations of fit statistics are in Appendix B; (b) $\mathrm{R}^{2}$ is the proportion of the variance of the variable that is explained by the variables affecting it.

According to Appendix B the fit statistics in Table 6 are satisfactory. However, in Figure 2 there are three direct effects that are small in magnitude and not statistically significant, and this raises the possibility that their removal from the model may produce a simpler model with improved fit statistics. Also, based on significant correlation coefficients (Appendix Table A3) it was noted above there are three plausible causal effects of Flow Experience, Technology Experience, and Technology SelfEfficacy on Attitude toward Use of Technology that may be added to the model. These six effects were made optional in the modified theoretical model, which produced a hierarchy of $2^{6}=64$ models, each of which was analyzed using the specification search facility available in the Amos software. As recommended by Kline (2005) the final model was selected as the one with the smallest value for Normed Chi-square (NC). The final model is shown in Figure 3. 


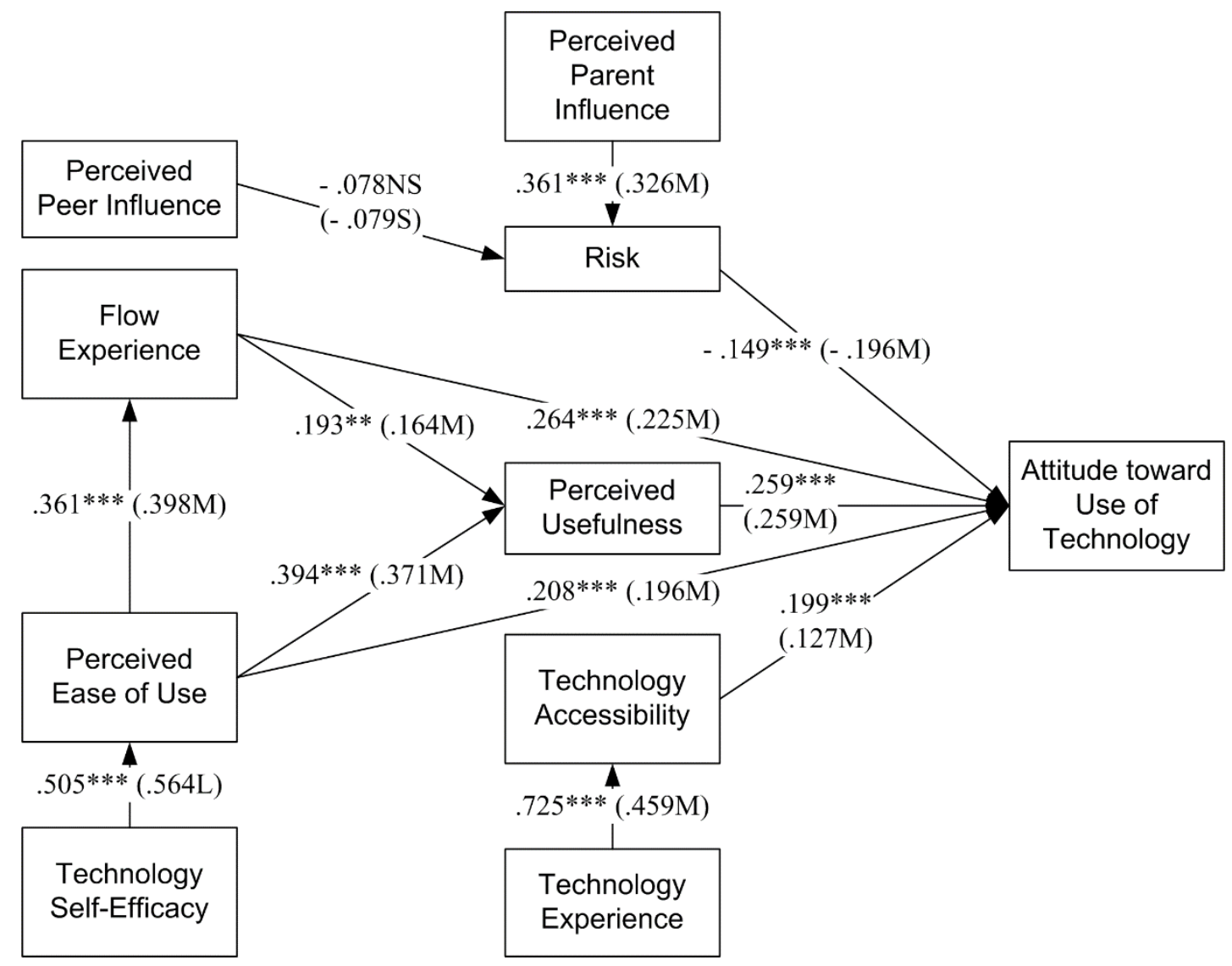

Figure 3: Final model

In Figure 3 there is only one direct effect that is not statistically significant at a level of 0.05 or less (Perceived Peer Influence $\rightarrow$ Risk) and it is small in magnitude. All of the other direct effects are statistically significant at a level of 0.01 or less and they are medium in magnitude with one large effect. Compared to the modified theoretical model in Figure 2, it is seen that in the final model Perceived Parent Influence $\rightarrow$ Attitude toward Use of Technology and Technology Self-Efficacy $\rightarrow$ Perceived Usefulness have been removed while Flow Experience $\rightarrow$ Attitude toward Use of Technology has been included. Fit statistics for the final model are displayed in Table 7.

Table 7: Fit statistics for the final model

\begin{tabular}{|l|c|r|r|r|r|r|r|r|}
\hline $\mathbf{N}$ & NC $\left(\boldsymbol{\chi}^{2} / \mathbf{d f}\right)$ & RMR & GFI & AGFI & NFI & IFI & CFI & \multicolumn{1}{c|}{ RMSEA } \\
\hline \multirow{2}{*}{460} & $768.217 / 387=1.985$ & .085 & .901 & .881 & 0.919 & 0.958 & 0.958 & 0.046 \\
\cline { 2 - 7 } & \multicolumn{2}{|l}{$\mathbf{R}^{2}$ : PEU (.319), FE (.159), TA (.211), PU (.213), R (.097), and AUT (.336) } \\
\hline
\end{tabular}

Notes: (a) Notes and interpretations of fit statistics are in Appendix B; (b) $\mathrm{R}^{2}$ is the proportion of the variance of the variable that is explained by the variables affecting it.

From Table 7 it is seen that the fit statistics for the final model are slightly improved compared to those in Table 6 for the modified theoretical model. However, the final model is recommended because it also contains one less causal effect compared to the modified theoretical model.

Table 8 displays the results of the analysis of all of the effects in the final model. In addition to the direct effects, which are displayed in Figure 3, Table 8 presents the full details of all of the indirect effects, the totals of indirect effects, as well as the totals of all effects. The statistical significance of unstandardized indirect effects, the totals of unstandardized indirect effects, and the totals of all un- 
standardized effects are not routinely reported when using Amos software. The statistical significance of these effects was determined according to the information provided in Appendix $C$ where in particular nonparametric bootstrapping was performed using 1,000 random samples.

Table 8: Analysis of the final model

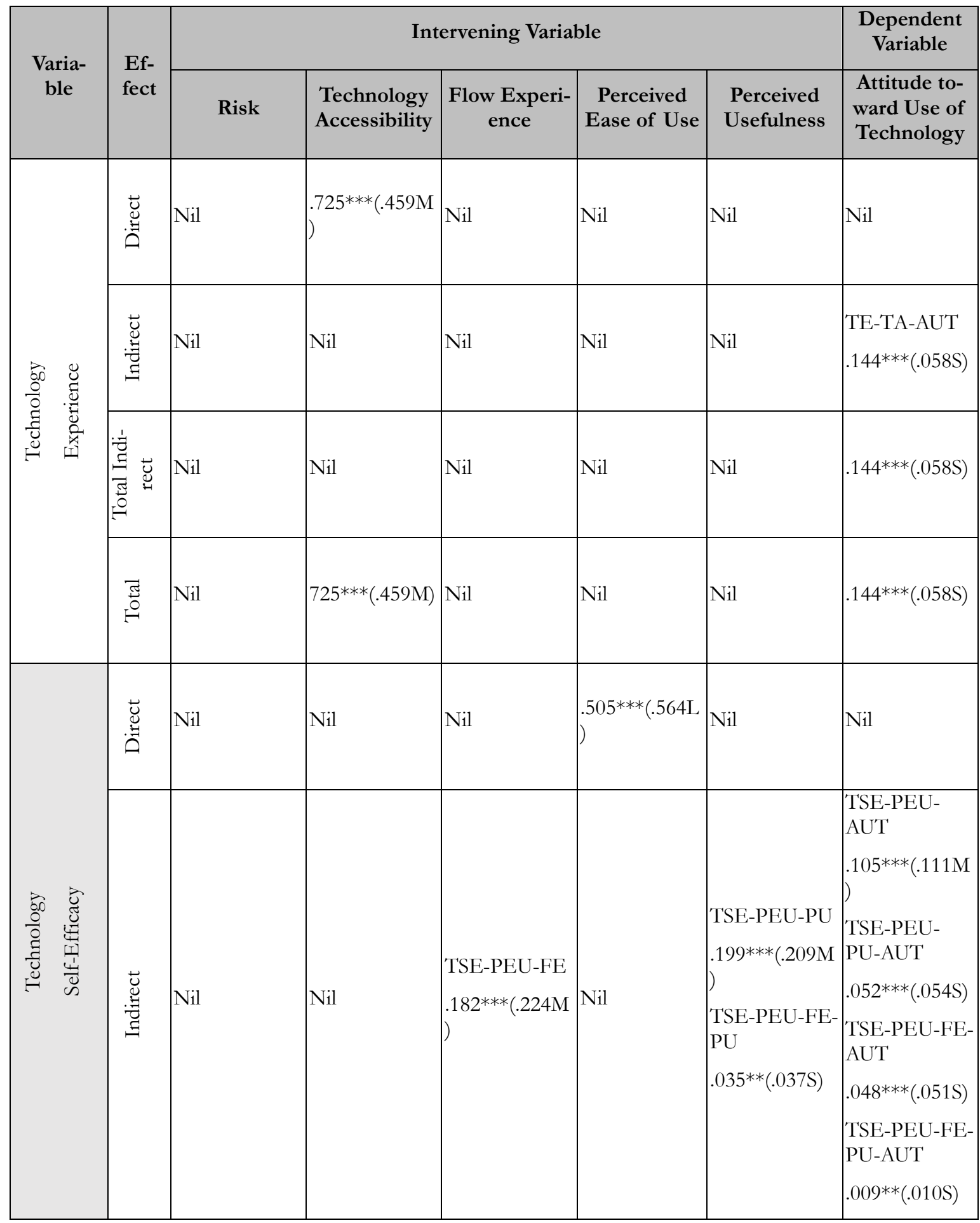


Kristianto

\begin{tabular}{|c|c|c|c|c|c|c|c|}
\hline \multirow{2}{*}{$\begin{array}{l}\text { Varia- } \\
\text { ble }\end{array}$} & \multirow{2}{*}{$\begin{array}{l}\text { Ef- } \\
\text { fect }\end{array}$} & \multicolumn{5}{|c|}{ Intervening Variable } & \multirow{2}{*}{\begin{tabular}{|c|}
$\begin{array}{l}\text { Dependent } \\
\text { Variable }\end{array}$ \\
$\begin{array}{l}\text { Attitude to- } \\
\text { ward Use of } \\
\text { Technology }\end{array}$ \\
\end{tabular}} \\
\hline & & Risk & $\begin{array}{l}\text { Technology } \\
\text { Accessibility }\end{array}$ & $\begin{array}{c}\text { Flow Experi- } \\
\text { ence }\end{array}$ & $\begin{array}{c}\text { Perceived } \\
\text { Ease of Use }\end{array}$ & $\begin{array}{l}\text { Perceived } \\
\text { Usefulness }\end{array}$ & \\
\hline & 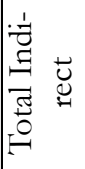 & Nil & Nil & $.182^{* * *}(.224 \mathrm{M}$ & Nil & $.234^{* *}(.246 \mathrm{M})$ & $.214^{* *}(.226 \mathrm{M})$ \\
\hline & స్త్ర & Nil & Nil & $.182^{* * *}(.224 \mathrm{M}$ & $.505^{* * *}(.564 \mathrm{~L}$ & $.234 * *(.246 \mathrm{M})$ & $.214^{* *}(.226 \mathrm{M})$ \\
\hline \multirow{4}{*}{ 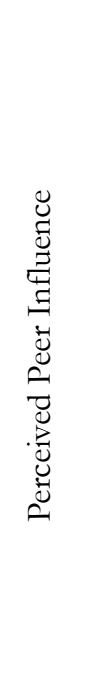 } & 苛 & $-.078^{\mathrm{NS}}(-.079 \mathrm{~S})$ & Nil & Nil & Nil & Nil & Nil \\
\hline & 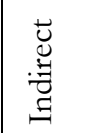 & Nil & Nil & Nil & Nil & Nil & $\begin{array}{l}\text { PPeI-R-AUT } \\
.012^{\mathrm{NS}}(.015 \mathrm{~S})\end{array}$ \\
\hline & 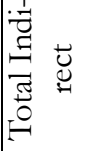 & Nil & Nil & Nil & Nil & Nil & $.012^{\mathrm{NS}}(.015 \mathrm{~S})$ \\
\hline & 胥 & $-.078^{\mathrm{NS}}(-.079 \mathrm{~S})$ & Nil & Nil & Nil & Nil & $.012^{\mathrm{NS}}(.015 \mathrm{~S})$ \\
\hline \multirow{4}{*}{ 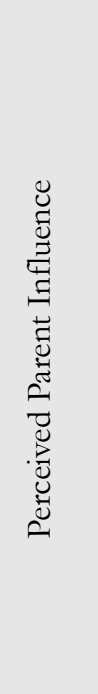 } & 苞 & $.361 * * *(.326 \mathrm{M}$ & Nil & Nil & Nil & Nil & Nil \\
\hline & 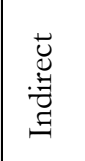 & Nil & Nil & Nil & Nil & Nil & $\begin{array}{l}\text { PPaI-R-AUT } \\
-.054^{* * *}(- \\
.064 \mathrm{~S})\end{array}$ \\
\hline & 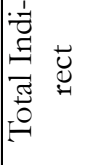 & Nil & Nil & Nil & Nil & Nil & $\begin{array}{l}-.054 * * *(- \\
.064 \mathrm{~S})\end{array}$ \\
\hline & 胥 & $.361 * * *(.326 \mathrm{M}$ & Nil & Nil & Nil & Nil & $\begin{array}{l}-.054 * * *(- \\
.064 \mathrm{~S})\end{array}$ \\
\hline
\end{tabular}


Factors Affecting Social Network Use by Students in Indonesia

\begin{tabular}{|c|c|c|c|c|c|c|c|}
\hline \multirow{2}{*}{$\begin{array}{c}\text { Varia- } \\
\text { ble }\end{array}$} & \multirow{2}{*}{$\begin{array}{l}\text { Ef- } \\
\text { fect }\end{array}$} & \multicolumn{5}{|c|}{ Intervening Variable } & \multirow{2}{*}{$\begin{array}{c}\begin{array}{c}\text { Dependent } \\
\text { Variable }\end{array} \\
\text { Attitude to- } \\
\text { ward Use of } \\
\text { Technology }\end{array}$} \\
\hline & & Risk & $\begin{array}{l}\text { Technology } \\
\text { Accessibility }\end{array}$ & $\begin{array}{c}\text { Flow Experi- } \\
\text { ence }\end{array}$ & $\begin{array}{c}\text { Perceived } \\
\text { Ease of Use }\end{array}$ & $\begin{array}{l}\text { Perceived } \\
\text { Usefulness }\end{array}$ & \\
\hline \multirow{4}{*}{ 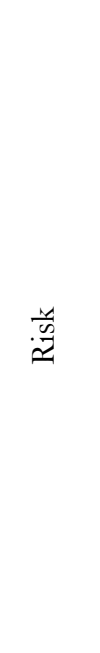 } & 节 & Nil & Nil & Nil & Nil & Nil & $\begin{array}{l}-.149 * * *(- \\
.196 \mathrm{M})\end{array}$ \\
\hline & 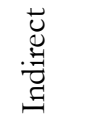 & Nil & Nil & Nil & Nil & Nil & Nil \\
\hline & 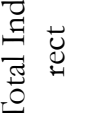 & Nil & Nil & Nil & Nil & Nil & Nil \\
\hline & 氶 & Nil & Nil & Nil & Nil & Nil & $\begin{array}{l}-.149 * * *(- \\
.196 \mathrm{M})\end{array}$ \\
\hline \multirow{4}{*}{ 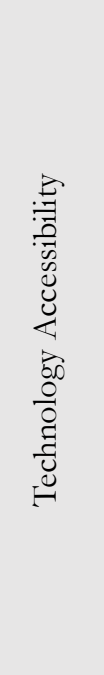 } & 苞 & Nil & Nil & Nil & Nil & Nil & $.199 * *(.127 \mathrm{M})$ \\
\hline & 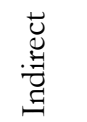 & Nil & Nil & Nil & Nil & Nil & Nil \\
\hline & 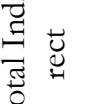 & Nil & Nil & Nil & Nil & Nil & Nil \\
\hline & 胥 & Nil & Nil & Nil & Nil & Nil & $.199 * *(.127 \mathrm{M})$ \\
\hline \multirow{2}{*}{ 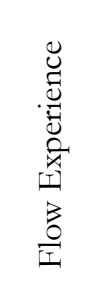 } & 㟥 & Nil & Nil & Nil & Nil & $193 * *(.164 \mathrm{M})$ & $.264 * * *(.225 \mathrm{M}$ \\
\hline & 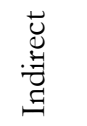 & Nil & Nil & Nil & Nil & Nil & $\begin{array}{l}\text { FE-PU-AUT } \\
.050^{* *}(.042 \mathrm{~S})\end{array}$ \\
\hline
\end{tabular}


Kristianto

\begin{tabular}{|c|c|c|c|c|c|c|c|}
\hline \multirow{2}{*}{$\begin{array}{l}\text { Varia- } \\
\text { ble }\end{array}$} & \multirow{2}{*}{$\begin{array}{l}\text { Ef- } \\
\text { fect }\end{array}$} & \multicolumn{5}{|c|}{ Intervening Variable } & \multirow{2}{*}{\begin{tabular}{|c|}
$\begin{array}{c}\text { Dependent } \\
\text { Variable }\end{array}$ \\
$\begin{array}{c}\text { Attitude to- } \\
\text { ward Use of } \\
\text { Technology }\end{array}$ \\
\end{tabular}} \\
\hline & & Risk & $\begin{array}{l}\text { Technology } \\
\text { Accessibility }\end{array}$ & $\begin{array}{c}\text { Flow Experi- } \\
\text { ence }\end{array}$ & $\begin{array}{c}\text { Perceived } \\
\text { Ease of Use }\end{array}$ & $\begin{array}{l}\text { Perceived } \\
\text { Usefulness }\end{array}$ & \\
\hline & 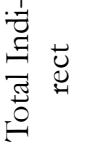 & Nil & Nil & Nil & Nil & Nil & $.050 * *(.042 S)$ \\
\hline & 丞 & Nil & Nil & Nil & Nil & $193 * *(.164 M)$ & $.314^{* *}(.267 \mathrm{M})$ \\
\hline \multirow{4}{*}{ 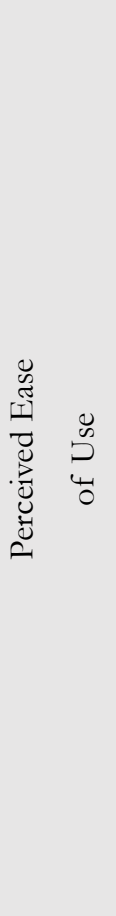 } & 苛 & Nil & Nil & $.361 * * *(.398 \mathrm{M}$ & Nil & $.394^{* * *}(.371 \mathrm{M}$ & $.208^{* * *}(.196 \mathrm{M}$ \\
\hline & $\begin{array}{l}\breve{U} \\
: \mathscr{\Xi} \\
:\end{array}$ & Nil & Nil & Nil & Nil & $\begin{array}{l}\text { PEU-FE-PU } \\
.070^{* *}(.065 S)\end{array}$ & $\begin{array}{l}\text { PEU-PU-AUT } \\
.102^{* * *}(.096 \mathrm{~S}) \\
\text { PEU-FE-AUT } \\
.095^{* * *}(.090 \mathrm{~S}) \\
\text { PEU-FE-PU- } \\
\text { AUT } \\
.018^{* *}(.017 \mathrm{~S})\end{array}$ \\
\hline & 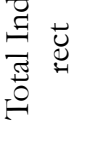 & Nil & Nil & Nil & Nil & $.070 * *(.065 \mathrm{~S})$ & $.215^{* *}(.203 \mathrm{M})$ \\
\hline & 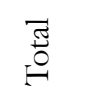 & Nil & Nil & $.361 * * *(.398 \mathrm{M}$ & Nil & $.464 * *(.436 \mathrm{M})$ & $.423 * *(.399 \mathrm{M})$ \\
\hline \multirow{3}{*}{ 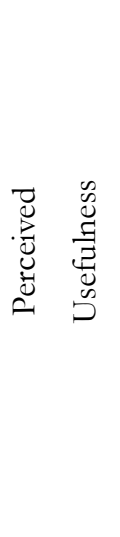 } & 苟 & Nil & Nil & Nil & Nil & Nil & $.259 * * *(.259 \mathrm{M}$ \\
\hline & 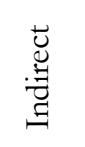 & Nil & Nil & Nil & Nil & Nil & Nil \\
\hline & 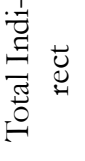 & Nil & Nil & Nil & Nil & Nil & Nil \\
\hline
\end{tabular}




\begin{tabular}{|c|c|c|c|c|c|c|c|}
\hline \multirow{2}{*}{$\begin{array}{l}\text { Varia- } \\
\text { ble }\end{array}$} & \multirow{2}{*}{$\begin{array}{l}\text { Ef- } \\
\text { fect }\end{array}$} & \multicolumn{5}{|c|}{ Intervening Variable } & \multirow{2}{*}{\begin{tabular}{|c|}
$\begin{array}{c}\text { Dependent } \\
\text { Variable }\end{array}$ \\
$\begin{array}{c}\text { Attitude to- } \\
\text { ward Use of } \\
\text { Technology }\end{array}$ \\
\end{tabular}} \\
\hline & & Risk & $\begin{array}{l}\text { Technology } \\
\text { Accessibility }\end{array}$ & $\begin{array}{c}\text { Flow Experi- } \\
\text { ence }\end{array}$ & $\begin{array}{c}\text { Perceived } \\
\text { Ease of Use }\end{array}$ & $\begin{array}{l}\text { Perceived } \\
\text { Usefulness }\end{array}$ & \\
\hline & 푱 & Nil & Nil & Nil & Nil & Nil & $.259 * * *(.259 \mathrm{M}$ \\
\hline
\end{tabular}

From Table 8 it is seen that all of the effects are statistically significant at a level of 0.01 or less except for the direct effect of Perceived Peer Influence on Risk, which is not statistically significant at a level of 0.05 or less. Several variables only have indirect effects on Attitude toward Use of Technology (Technology Experience, Technology Self-Efficacy, Perceived Peer Influence, and Perceived Parent Influence) and some only have a direct effect on Attitude toward Use of Technology (Risk, Perceived Usefulness, and Technology Accessibility). Two variables (Perceived Ease of Use and Flow Experience) have both direct and indirect effects on Attitude toward Use of Technology. For Perceived Ease of Use the direct effect is less than the total of the indirect effects, and this emphasizes the important role of the two intervening variables (Flow Experience and Perceived Usefulness) as mediators in the effect of Perceived Ease of Use on Attitude toward Use of Technology. All of the total effects are positive except for the total effect of Perceived Peer Influence on Risk, Perceived Parent Influence on Attitude toward Use of Technology, and Risk Attitude toward Use of Technology. Even though some total effects are small, they are statistically significant (e.g., the total effect of Technology Experience on Attitude toward Use of Technology), and this highlights the need to focus on the magnitude and direction of effects rather than considering only their statistical significance.

In summary, the initial theoretical model had eleven constructs. Based on the data preparation that involved principal component factor analysis, it is found that the three indicators PE1, PE2, and PE3 for Perceived Enjoyment each loaded significantly onto the latent variable Attitude toward Use of Technology with three indicators AUT1, AUT2, and AUT3. Consequently, the variable Perceived Enjoyment and its associated hypothesis were removed from the theoretical model because its indicators actually measured Attitude toward Use of Technology. This process formed the modified theoretical model with ten constructs. By using SEM analysis, it is found that three direct effects are not statistically significant. Referred to the fit statistics for the modified theoretical model, these causal effects were removed from the modified model. Also, based on significant correlation coefficients it is noted that there are three plausible causal effects of Flow Experience, Technology Experience, and Technology Self-Efficacy on Attitude toward Use of Technology that may be added to the model. The one with the smallest value for Normed Chi-square (NC) was added to the final model.

\section{DISCUSSION OF THE FINDINGS}

This section presents an interpretation of the total effects of each variable in the final model, a comparison of the findings of the study with those from previous studies, which motivated the development of the theoretical model (Figure 1), a discussion of new findings, and the practical implications of the findings.

\section{INTERPRETATION OF TOTAL EFFECTS}

Table 9 summarizes the total effects in the final model shown in Table 8. 
Table 9: Summary of total effects in the final model

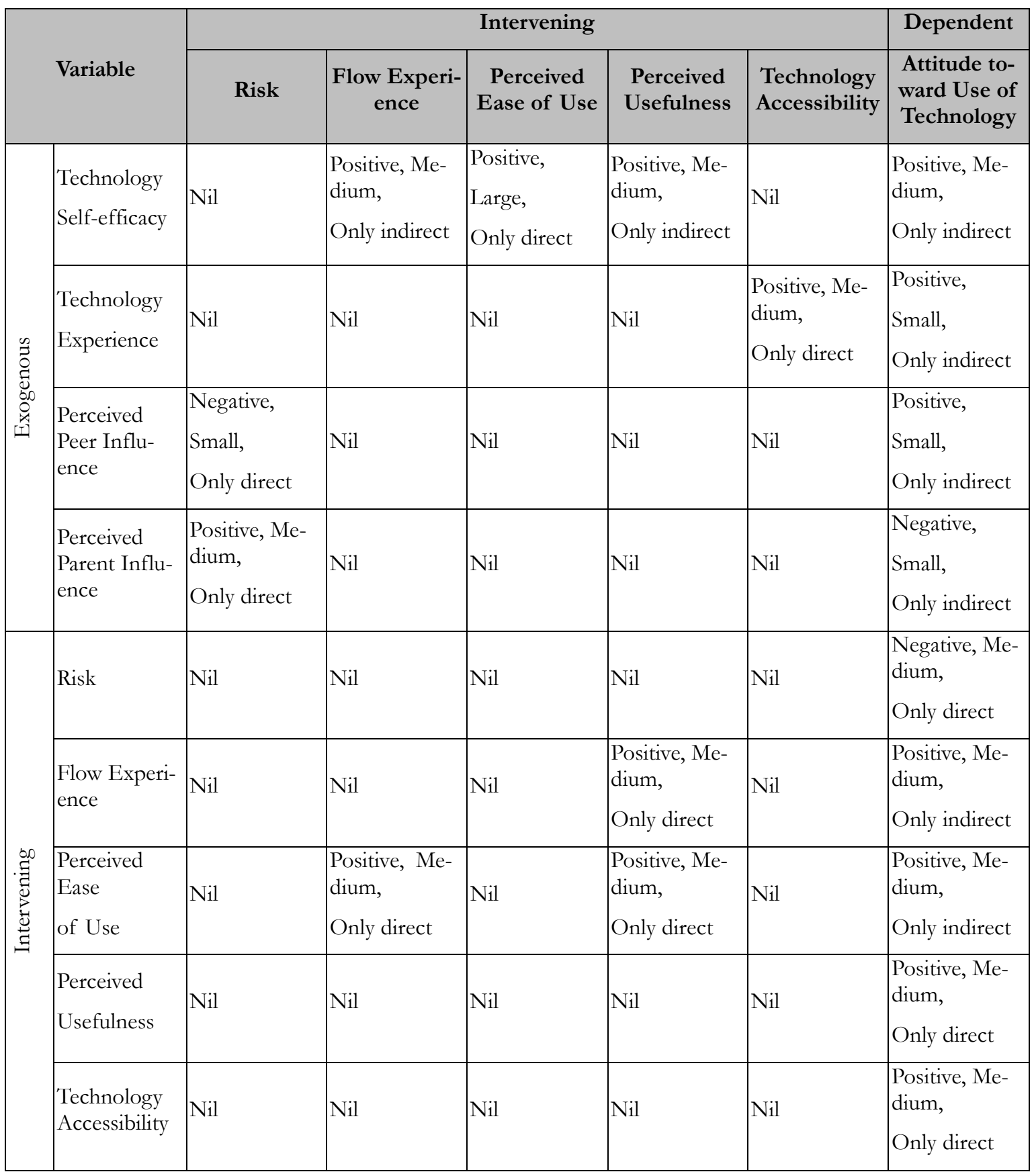

The discussion begins by considering effects on the dependent variable Attitude toward Use of Technology due to the other nine model variables. This is followed by considering other effects involving the intervening variables and the exogenous variables.

\section{The dependent variable (Attitude toward Use of Technology)}

Perceived Ease of Use has the largest positive effect on Attitude toward Use of Technology followed in order of magnitude by the five important medium effects of Flow Experience, Perceived Usefulness, Technology Self-efficacy, Risk, and Technology Accessibility. All these total effects on Attitude toward Use of Technology are positive except for the effect of Risk whereby as awareness of risk in 
using SNS increases the child's attitude becomes less positive. Also, it is noted in relation to the total effect due to Technology Accessibility that children have a relatively low capability of accessing or purchasing technologies from their own resources while adults generally have greater access to technologies. Consequently, for children effects due to Technology Accessibility are very dependent on resources provided by their parents. These six total effects on Attitude toward Use of Technology are followed in order of magnitude by three small relatively unimportant effects due to Technology Experience, Perceived Parent Influence, and Perceived Peer Influence.

Among these results, which are based on total effects and consequently include direct effects and indirect effects, there is general agreement with direct effects on Attitude toward Use of Technology reported in previous studies and introduced in the theoretical model caused by Perceived Ease of Use and Perceived Usefulness (Davis et al., 1989), Technology Accessibility (Zhang, 2010); Risk (Renny et al., 2013; T. Wang \& Tseng, 2011); and Perceived Parent Influence (Karuppiah, 2014; W. Shin \& Ismail, 2014).

\section{Intervening variables}

Perceived Usefulness has an important positive effect on only Attitude toward Use of Technology. It is affected positively (in decreasing order of importance) by Perceived Ease of Use, Technology Selfefficacy, and Flow Experience.

Apart from the important effect of Perceived Ease of Use on Attitude toward Use of Technology, this intervening variable has important positive medium effects on Perceived Usefulness and Flow Experience. On the other hand, Perceived Ease of Use is positively influenced by only the exogenous variable Technology Self-Efficacy. Also, it is noted that the direct effect of Perceived Ease of Use on Attitude toward Use of Technology is less than the total of the indirect effects through the two intervening variables Perceived Usefulness and Flow Experience. This highlights the important mediation role played by these two variables in the influence of Perceived Ease of Use on Attitude toward Use of Technology.

Flow Experience has an important positive effect on Attitude toward Use of Technology and a positive medium effect on Perceived Usefulness. As noted above, Perceived Ease of Use has an important positive effect on Flow Experience, and Technology Self-efficacy has a slightly less but still important positive indirect effect.

Among these results, which are based on total effects and consequently include direct effects and indirect effects, there is general agreement with the direct effects reported in previous studies and introduced in the theoretical model caused by Perceived Ease of Use (Davis et al., 1989; Hsu \& Lu, 2004), Technology Self-efficacy (Hong et al., 2013), and Flow Experience (Chang \& Zhu, 2012; Ernst et al., 2013; Gao \& Bai, 2014).

\section{Exogenous variables}

Technology Self-efficacy has important positive effects (in decreasing order of importance) on Perceived Ease of Use, Perceived Usefulness, Attitude toward Use of Technology, and Flow Experience. Technology Experience has a small unimportant effect on Attitude toward Use of Technology. However, it is the only determinant of Technology Accessibility with an important positive direct effect. As noted above for the effect of Technology Accessibility, it is recognized that children are dependent on parental involvement to a large extent for the resources associated with Technology Selfefficacy and Technology Experience.

Perceived Parent Influence only has a small unimportant indirect negative effect on Attitude toward Use of Technology but it has an important positive medium direct effect on Risk. The effect of Perceived Parent Influence on Risk means that the more parents want to know what their child does with SNS, tell their child not to do particular acts through SNS, and complain when their child does something with SNS that they don't like then the less likely it is that the child will believe that SNS is 
a secure system, the SNS provider's promises and commitments are true, and chatting, uploading, and downloading images on SNS are secure. Perceived Peer Influence only has a small positive indirect effect on Attitude toward Use of Technology resulting from a small unimportant negative effect on the intervening variable Risk whereby other children tend to influence a child that using SNS does not involve any risks.

Among these results, which are based on total effects and consequently include direct effects and indirect effects, there is general agreement with the direct effects reported in previous studies and introduced in the theoretical model caused by Technology Self-efficacy (Hong et al., 2013), Technology Experience (Park \& Lee, 2012), Perceived Parent Influence (Karuppiah, 2014; W. Shin \& Ismail, 2014), and Perceived Peer Influence (W. Shin \& Ismail, 2014).

\section{COMPARISON WITH THE FINDINGS OF PREVIOUS STUDIES}

Table 10 displays the decisions with respect to the research hypothesis for the study, which are concerned with only direct effects specifically derived from the previous studies referenced in Table 10. Section 1 includes hypothesis that were fully supported. Section 2 includes the only hypothesis for which there was no support. Section 3 includes hypothesis that were only partially supported. This means that although the hypothesized significant causal effect was not supported there was a significant correlation between the variables (Table A3) in the hypothesis with the same direction as the hypothesized causal effect.

Table 10: Decisions for the research hypothesis

\begin{tabular}{|c|c|c|}
\hline & Hypothesis & Reference \\
\hline \multicolumn{3}{|c|}{ Section 1: Supported by the Findings } \\
\hline $\mathrm{H} 2$ & $\begin{array}{l}\text { Perceived Ease of Use has a significant positive direct effect on Flow Experi- } \\
\text { ence }\end{array}$ & Hsu \& Lu (2004) \\
\hline $\mathrm{H} 4$ & $\begin{array}{l}\text { Perceived Ease of Use has a significant positive direct effect on Perceived Use- } \\
\text { fulness }\end{array}$ & Davis et al. (1989) \\
\hline H5 & $\begin{array}{l}\text { Perceived Ease of Use has a significant positive direct effect on Attitude toward } \\
\text { Use of Technology }\end{array}$ & Davis et al. (1989) \\
\hline H6 & $\begin{array}{l}\text { Technology Self-Efficacy has a significant positive direct effect on Perceived } \\
\text { Ease of Use }\end{array}$ & Hong et al. (2013) \\
\hline H9 & $\begin{array}{l}\text { Technology Experience has a significant positive direct effect on Technology } \\
\text { Accessibility }\end{array}$ & Park \& Lee (2012) \\
\hline H10 & $\begin{array}{l}\text { Technology Accessibility has a significant positive direct effect on Attitude to- } \\
\text { ward Use of Technology }\end{array}$ & Zhang (2010) \\
\hline H11 & $\begin{array}{l}\text { Perceived Usefulness has a significant positive direct effect on Attitude toward } \\
\text { Use of Technology }\end{array}$ & Davis et al. (1989) \\
\hline H13 & Perceived Parent Influence has a significant positive direct effect on Risk & $\begin{array}{l}\text { W. Shin \& Ismail (2014), } \\
\text { Karuppiah (2014) }\end{array}$ \\
\hline H15 & $\begin{array}{l}\text { Risk has a significant negative direct effect on Attitude toward Use of Technol- } \\
\text { ogy }\end{array}$ & $\begin{array}{l}\text { Wang \& Tseng (2011), } \\
\text { Renny et al. (2013) }\end{array}$ \\
\hline H16 & Flow Experience has a significant direct effect on Perceived Usefulness & $\begin{array}{l}\text { Gao \& Bai (2014), } \\
\text { Chang \& Zhu (2012), } \\
\text { Ernst et al. (2013) }\end{array}$ \\
\hline \multicolumn{3}{|c|}{ Section 2: Not Supported by the Findings } \\
\hline H12 & Perceived Peer Influence has a significant negative direct effect on Risk & W. Shin \& Ismail (2014) \\
\hline
\end{tabular}




\begin{tabular}{|c|l|l|l|}
\hline \multicolumn{2}{|c|}{ Section 3: Partially Supported by the Findings } \\
\hline Hypothesis & \multicolumn{1}{c|}{ Reference } & Comment \\
\hline H7 & $\begin{array}{l}\text { Technology Self-Efficacy has a significant positive } \\
\text { direct effect on Perceived Usefulness }\end{array}$ & Hong et al. (2013) & $\begin{array}{l}\text { Significant positive } \\
\text { correlation }\end{array}$ \\
\hline H14 & $\begin{array}{l}\text { Perceived Parent Influence has a significant negative } \\
\text { direct effect on Attitude toward Use of Technology }\end{array}$ & $\begin{array}{l}\text { W. Shin \& Ismail (2014), } \\
\text { Karuppiah (2014) }\end{array}$ & $\begin{array}{l}\text { Significant negative } \\
\text { correlation }\end{array}$ \\
\hline
\end{tabular}

Note: Perceived Enjoyment was deleted from the theoretical model because of unsatisfactory construct validity and consequently the three research hypothesis in Table 4 (H1, H3, and H8) were not able to be tested.

From Table 10 it is seen that the findings provided support for most of the findings in referenced previous studies. However, there were new findings.

\section{NEW FINDINGS}

Table 11 displays findings from the study shown in Table 8 and Table 10, which are not reported in previous studies and need to be validated in future studies.

\section{Table 11: New findings}

\begin{tabular}{l} 
Explanation of new findings \\
\hline 1. Perceived Peer Influence does: \\
(a) Not have a statistically significant direct effect on Risk. \\
(b) Not have a statistically significant indirect effect on Attitude toward Use of Technology. \\
(c) Not have a statistically significant correlation with Risk or Attitude toward Use of Technology. \\
(d) Have a statistically significant positive correlation with Perceived Parent Influence.
\end{tabular}

\section{Perceived Parent Influence does:}

(a) Not have a statistically significant direct effect on Attitude toward Use of Technology.

(b) Have a statistically significant indirect negative effect on Attitude toward Use of Technology through the mediation effect of Risk.

(c) Have a statistically significant negative correlation with Attitude toward Use of Technology.

\section{Technology Self-Efficacy does:}

(a) Not have a statistically significant positive direct causal effect on Perceived Usefulness.

(b) Have a statistically significant positive correlation with Perceived Usefulness.

(c) Have statistically significant indirect positive effects on Perceived Usefulness through the mediations effects of Perceived Ease of Use and Flow Experience.

4. Flow Experience has a statistically significant positive:

(a) Direct effect on Attitude toward Use of Technology.

(b) Correlation with Attitude toward Use of Technology

From the Table 11 it is seen that among these new findings many involve Perceived Peer Influence, Perceived Parent Influence, Risk, and Attitude toward Use of Technology. There was support for the finding by W. Shin and Ismail (2014) and Karuppiah (2014) that Perceived Parent Influence has a significant positive direct effect on Risk as well as the finding by T. Wang and Tseng (2011) and Renny et al. (2013) that Risk has a significant negative direct effect on Attitude toward Use of Technology. However, there was no support for a significant direct negative effect of Perceived Parent Influ- 
ence on Attitude toward Use of Technology reported by W. Shin and Ismail (2014) and Karuppiah (2014). Instead, the effect of Perceived Parent Influence on Attitude toward Use of Technology was indirect, negative, and only small via the mediation role of Risk. However, from an analysis of correlation those children who experienced high levels of parental influence had less favorable attitudes towards SNS. This supports the finding by Lee (2015) that children in primary school grades 4, 5, or 6 are able to think critically and have a strong sense of fairness and right and wrong, and they do understand the advice given by parents and they can make informed judgments based on that advice. Consequently, if parents enquire into their children's activities on SNS and advise them on what to do on SNS, this advice is understood and causes the children to be aware of the risks of using SNS relating to security and the promises and commitments made by providers. This direct positive effect of parental influence on the child's awareness of the risks in using SNS is compatible with the collectivist nature of Indonesian society where the influence of parents on children is significant (Hofstede, 1990).

It might be assumed children in primary school grades 4,5 , or 6 will be strongly influenced by their peers. However, the finding by W. Shin and Ismail (2014) that Perceived Peer Influence has a significant negative direct effect on Risk was not supported. Instead, increasing the influence of peers caused only a small negative but not statistically significant decrease in the children's belief that there are risks in using SNS. In addition, even though the indirect effect of Perceived Peer Influence on Attitude toward Use of Technology via Risk was positive, it was only small and not statistically significant. Based on analysis of correlation the children who were most influenced by their peers were also strongly influenced by their parents. Lourenco et al. (2015) found that advice from older people influences adolescents and adults more than advice from their peers. They concluded that the perceived quality of the advice appears to determine how strongly it is followed with individuals preferring advisors who appear to be more credible. Thus, relying on advice from experts may provide a cognitive shortcut by "offloading" the evaluations that inform a decision. Consequently, although children in primary school grades 4, 5, or 6 may be influenced by their peers on issues related to social relationships and activities, peers are nowhere near as influential as parents when the issues concern awareness of the risks of using SNS and the formation of attitudes toward the use of SNS.

In summary, this study found that children's views about the risks associated with the use of SNS are strongly influenced by their parents but not their peers. Peers only have a small positive effect on a child's attitude towards the use of SNS but increased parental influence acted indirectly to reduce the children's positive attitudes to the use of SNS by increasing significantly their awareness of the extent to which using SNS may expose them to a dangerous situation. It is evident that parental involvement also plays an important role in providing support and resources that increase their children's levels of Technology Experience, Technology Accessibility, and Technology Self-Efficacy, and these effects do tend to encourage the children to have a positive attitude toward the use of SNS.

Flow Experience has a significant positive direct effect on Attitude toward Use of Technology, and children who experience high levels of Flow Experience also have a very positive Attitude toward Use of Technology. This new finding appears in the final model where Flow Experience has an important direct effect on Attitude toward Use of Technology in addition to its indirect effect through Perceived Usefulness. Once a child experiences increased flow experience, using SNS strengthens a positive attitude to the SNS both directly and indirectly by strengthening the child's perception that SNS is useful to him or her. In practice, this direct effect of Flow Experience on Attitude toward Use of Technology is similar to the indirect effect via Perceived Enjoyment reported by Gao and Bai (2014), Chang and Zhu (2012), and Ernst et al. (2013).

Technology Self-Efficacy does not have a statistically significant positive direct effect on Perceived Usefulness as proposed by Hong et al. (2013). However, it has statistically significant positive indirect effects on Perceived Usefulness through the mediation effects of Perceived Ease of Use and Flow Experience, which have not been reported in previous studies. Also, analysis of correlation (Table A3) showed that those children with strong beliefs in their capabilities to use SNS found SNS to be 
very useful to them, which does partially support the statistically significant positive direct effect of Technology Self-Efficacy on Perceived Usefulness reported by Hong et al. (2013).

In summary, from a theoretical perspective, the findings of the study show that many of the constructs and their relationships, which were derived from previous studies, and incorporated in the theoretical model (Figure 1) were supported. However, new effects were found involving the influences of parents and peers on children's perceptions of the risks associated with using SNS as well as their overall attitude toward the use of SNS. Flow experience was found to be a very important direct influence on the children's attitudes to SNS. Flow Experience as well as perceptions of the usefulness of SNS is an important mediator in the effect of the ease of use of SNS and on the children's attitudes towards the use of SNS.

\section{PRACTICAL IMPLICATIONS OF THE FINDINGS}

From a practical perspective, the results in Table 8 enable a hierarchy of practical objectives and associated actions, to be proposed, which are aimed at the primary objective of increasing a positive attitude toward the use of SNS among children. This hierarchy of objectives and actions is presented in Table 12, where the actions are organized in an order of decreasing effect on the objectives, and the model variable associated with each action or objective is identified. In order to focus on the objectives and actions of primary importance the actions associated with small effects in the final model are not included.

Table 12: Practical objectives and actions to form a positive attitude toward the use of SNS

\begin{tabular}{|c|c|c|}
\hline Objectives & Actions & Model Variable \\
\hline \multirow{6}{*}{$\begin{array}{l}\text { Primary Objective: } \\
\text { Increase the extent to which a child has a } \\
\text { favorable evaluation or appraisal of SNS } \\
\text { (Attitude toward Use of Technology). }\end{array}$} & $\begin{array}{l}\text { 1. Ensure that the use of SNS is free of effort. } \\
\text { See Secondary Objective } 1 .\end{array}$ & $\begin{array}{l}\text { Perceived Ease } \\
\text { of Use }\end{array}$ \\
\hline & $\begin{array}{l}\text { 2. Ensure that SNS users have a holistic experi- } \\
\text { ence of total involvement. See Secondary Objective } \\
\text { 2. }\end{array}$ & $\begin{array}{l}\text { Flow Experi- } \\
\text { ence }\end{array}$ \\
\hline & $\begin{array}{l}\text { 3. Ensure that the user feels that the SNS is use- } \\
\text { ful for achieving their purpose Secondary Objective } \\
\text { 3. }\end{array}$ & $\begin{array}{l}\text { Perceived Use- } \\
\text { fulness }\end{array}$ \\
\hline & $\begin{array}{l}\text { 4. Ensure that users feel that they have the tech- } \\
\text { nical capability to use SNS. }\end{array}$ & $\begin{array}{l}\text { Technology } \\
\text { Self-Efficacy }\end{array}$ \\
\hline & $\begin{array}{l}\text { 5. Ensure that users feel that the use of the SNS } \\
\text { is free from risk. See Secondary Objective } 4 .\end{array}$ & Risk \\
\hline & $\begin{array}{l}\text { 6. Ensure that users have relatively inexpensive } \\
\text { access to the SNS. Secondary Objective } 5 .\end{array}$ & $\begin{array}{l}\text { Technology } \\
\text { Accessibility }\end{array}$ \\
\hline $\begin{array}{l}\text { Secondary Objective 1: } \\
\text { Ensure that the use of SNS is free of effort } \\
\text { (Perceived Ease of Use) }\end{array}$ & $\begin{array}{l}\text { 1.1 Ensure that users feel that they have the } \\
\text { technical capability to use SNS. }\end{array}$ & $\begin{array}{l}\text { Technology } \\
\text { Self-Efficacy }\end{array}$ \\
\hline \multirow{2}{*}{$\begin{array}{l}\text { Secondary Objective 2: } \\
\text { Ensure that SNS users have a holistic expe- } \\
\text { rience of total involvement (Flow Experi- } \\
\text { ence) }\end{array}$} & $\begin{array}{l}\text { 2.1 Ensure that the use of SNS is free of effort. } \\
\text { See Secondary Objective } 1 .\end{array}$ & $\begin{array}{l}\text { Perceived Ease } \\
\text { of Use }\end{array}$ \\
\hline & $\begin{array}{l}\text { 2.2 Ensure that users feel that they have the } \\
\text { technical capability to use SNS. }\end{array}$ & $\begin{array}{l}\text { Technology } \\
\text { Self-Efficacy }\end{array}$ \\
\hline
\end{tabular}




\begin{tabular}{|c|c|c|}
\hline Objectives & Actions & Model Variable \\
\hline \multirow{3}{*}{$\begin{array}{l}\text { Secondary Objective 3: } \\
\text { Ensure that the user feels that the SNS is } \\
\text { useful for achieving their purpose (Per- } \\
\text { ceived Usefulness). }\end{array}$} & $\begin{array}{l}\text { 3.1 Ensure that the use of SNS is free of effort. } \\
\text { See Secondary Objective } 1 .\end{array}$ & $\begin{array}{l}\text { Perceived Ease } \\
\text { of Use }\end{array}$ \\
\hline & $\begin{array}{l}\text { 3.2 Ensure that users feel that they have the } \\
\text { technical capability to use SNS. }\end{array}$ & $\begin{array}{l}\text { Technology } \\
\text { Self-Efficacy }\end{array}$ \\
\hline & $\begin{array}{l}\text { 3.3 Ensure that SNS users have a holistic experi- } \\
\text { ence of total involvement. See Secondary Objective } \\
\text { 2. }\end{array}$ & $\begin{array}{l}\text { Flow Experi- } \\
\text { ence }\end{array}$ \\
\hline $\begin{array}{l}\text { Secondary Objective 4: } \\
\text { Ensure that users feel that the use of the } \\
\text { SNS is free from risk (Risk). }\end{array}$ & $\begin{array}{l}\text { 4.1 Change the current influence by parents to } \\
\text { one whereby children are influenced by parents } \\
\text { to believe that SNS are relatively free of risk. }\end{array}$ & $\begin{array}{l}\text { Perceived Par- } \\
\text { ent Influence }\end{array}$ \\
\hline $\begin{array}{l}\text { Secondary Objective 5: } \\
\text { Ensure that users have relatively inexpensive } \\
\text { access to the SNS (Technology Accessibil- } \\
\text { ity). }\end{array}$ & $\begin{array}{l}\text { 5.1 Ensure that users have the knowledge and } \\
\text { skills related to the use of SNS. }\end{array}$ & $\begin{array}{l}\text { Technology } \\
\text { Experience }\end{array}$ \\
\hline
\end{tabular}

Note: If the primary objective was to discourage children's attitude to the use of SNS then the opposite actions and objectives would be specified.

In relation to the actions specified in Table 12, it is possible to suggest some of the practical means by which these actions may be executed, and these are summarized in Table 13 .

Table 13: Practical means associated with actions in Table 12

\begin{tabular}{|c|c|}
\hline is (Related Variables) & Means of Executing Actions \\
\hline \multirow{3}{*}{$\begin{array}{l}\text { 1. Increase the parents' understandings and tech- } \\
\text { nology experience to better influence children about } \\
\text { the risks associated with SNS usage. } \\
\text { (Perceived Parent Influence, Risk, and Attitude to- } \\
\text { ward Use of Technology) }\end{array}$} & $\begin{array}{l}\text { 1.1 Organize free seminars for parents about technology } \\
\text { understanding and usage. }\end{array}$ \\
\hline & $\begin{array}{l}\text { 1.2 Organize technology exhibition and invite parents to } \\
\text { attend for free. Make the goal is to increase a parent's un- } \\
\text { derstanding about technology, not the sales. }\end{array}$ \\
\hline & $\begin{array}{l}\text { 1.3 Set up free online assistan } \\
\text { technology-related problems a }\end{array}$ \\
\hline \multirow{4}{*}{$\begin{array}{l}\text { 2. Provide hardware and software at home to let } \\
\text { children easily access SNS. } \\
\text { (Technology Self-Efficacy, Technology Accessibility, } \\
\text { and Technology Experience) }\end{array}$} & $\begin{array}{l}\text { 2.1 Offer attractive sales bun } \\
\text { ble price for family. }\end{array}$ \\
\hline & 2.2 Donate hardware and software to schools, s \\
\hline & \\
\hline & $\begin{array}{l}\text { 2.3 Organize children-friendly technology exhibition to } \\
\text { attract children to come and try technology. }\end{array}$ \\
\hline \multirow{2}{*}{$\begin{array}{l}\text { 3. Provide children-friendly hardware and software } \\
\text { to increase children's SNS experience. } \\
\text { (Technology Experience and Technology Self- } \\
\text { Efficacy) }\end{array}$} & $\begin{array}{l}\text { 3.1 Develop games about children-friendly technology } \\
\text { usage to attract children's curiosity. }\end{array}$ \\
\hline & 3.2 Organize competitions for children about SNS usage. \\
\hline \multirow{2}{*}{$\begin{array}{l}\text { 4. Provide cheaper and attractive technologies to } \\
\text { increase accessibility and children's interest so that } \\
\text { they are attracted to use SNS. } \\
\text { (Technology Self-Efficacy, Technology Accessibility, } \\
\text { and Technology Experience) }\end{array}$} & $\begin{array}{l}\text { 4.1 Gather children's opinions and expectations about } \\
\text { SNS. }\end{array}$ \\
\hline & $\begin{array}{l}\text { 4.2 Develop cheap-children-friendly hardware and soft- } \\
\text { ware with simple-attractive functions, not complicated } \\
\text { functions. }\end{array}$ \\
\hline
\end{tabular}




\section{CONCLUSION}

The findings of the study identified six important factors that influence the attitudes of children to the use of SNS (Perceived Ease of Use, Flow Experience, Perceived Usefulness, Technology Selfefficacy, Risk, and Technology Accessibility) followed by three less important effects due to Technology Experience, Perceived Parent Influence, and Perceived Peer Influence. It is noted that the six important influences on the attitudes of children to the use of SNS support findings reported in previous studies and in particular the importance of the basic TAM constructs (Perceived Ease of Use and Perceived Usefulness). Also, the study has reported on indirect as well as direct effects among model variables. This has highlighted several findings concerned with indirect effects, which are not commonly reported in previous studies (see Tables 8, 9, and 11).

Different from the findings in some previous studies (e.g., Karuppiah, 2014; Renny et al., 2013; W. Shin \& Ismail, 2014; Wang \& Tseng, 2011) the direct and indirect effects on children's attitudes to the use of SNS due to parents and peers are less important. Instead, as reported by W. Shin and Ismail (2014) and Karuppiah (2014) the main effect of parental influence is to increase children's awareness of the risks associated with using SNS. On the other hand, peer influence has only a small insignificant effect of decreasing children's awareness of the risks associated with using SNS. This contrast between the effects of parent and peer influences on the awareness of risk may be explained by the finding by Lourenco et al. (2015) that advice from older people influences younger people more than advice from their peers because of a preference for quality advice from those who appear to be more credible or expert. Consequently, although children in primary school grades 4, 5, or 6 may be influenced by their peers for issues related to social relationships and activities, peers are nowhere near as influential as parents when the issues concern awareness of the risks of using SNS and the formation of attitudes toward the use of SNS. In addition, analysis of correlations supported these findings related to causal effects and showed that the children experiencing high levels of parental influence also experienced high levels of peer influence. The children experiencing high levels of parental influence were very aware of the risks of using SNS and expressed less positive attitudes to the use of SNS while peer influence was not significantly correlated with either awareness of risk or attitude to the use of SNS.

There are other issues related to the influence of parents that are implicit in the findings. It may be assumed that the parents of these young children are also users of SNS and consequently it is unlikely that parental influence would be such that it strongly discouraged children to use SNS. Instead, as the findings suggest it is more likely that parents would want their children to use SNS but with full awareness of the risks. The children are very dependent on their parents for support and resources associated with their use of SNS and so parents were influential in the positive influences on children's attitudes toward using SNS due to the factors of Technology Self-efficacy, Technology Accessibility, and Technology Experience.

There are limitations on the study. Measures for the latent variable Perceived Enjoyment coincided with the measures for the variable Attitude toward Use of Technology, and so Perceived Enjoyment was deleted from the theoretical model. Although, according to Davis et al. (1992), this is a common result, it is suggested that the relationship between these two variables be investigated in further studies. This appears to be the first study of this kind conducted with primary school children in the context of urban areas in Indonesia. A sampling frame was not available and so a purposive sampling method was used to select a sample of children from five cites (Semarang, Solo, Boyolali, Klaten, and Jakarta). Indonesia is a large archipelago with thousands of islands and so the external validity of the findings may be questioned and it is strongly recommended that the study be repeated using samples from schools in other urban areas. According to Lee (2015) children in the primary school grades 4, 5 , and 6 in this study are able to complete complex questionnaires. The questionnaire was administered very carefully ensuring that first hand guidance was readily available to children as they worked through the questionnaire, and it is not expected that the age of the children or the administration of the questionnaire has posed any serious limitations on the findings. Despite limitations it is expected 
that the findings contribute to a theoretical understanding of the factors that influence children's attitude toward the use of SNS, especially with regard to parent and peer influences on children's use of SNS. Also, the findings are expected to provide practical insights as to how children's attitudes to the use of SNS may be improved. The findings are of particular interest to parents and those involved in the social and educational development of children at present and in a future where it is expected that SNS will play an increasingly important role. The findings are of practical relevance to those who are responsible for the provision, development, and operation of SNS.

There are a number of related studies that could be done in the future including studies that enable comparisons between rural and urban students, that involve different age groups (e.g., adolescents and young and old adults), that enable comparisons between male and female subjects, and that incorporate specific cultural characteristics of Indonesian society and enable cross cultural comparisons.

\section{ACKNOWLEDGEMENT}

The author gratefully acknowledges the support for this research from the Post-Graduate Education Scholarship (2014-2017) of the Ministry of Research, Technology and Higher Education of the Republic of Indonesia as well as support from Satya Wacana Christian University, Indonesia.

\section{REFERENCES}

Ai, F., Comfort, L., Dong, Y., \& Znati, T. (2015). A dynamic decision support system based on geographical information and mobile social networks: A model for tsunami risk mitigation in Padang, Indonesia. Journal of Safety Science, 90, 62-74.

Ajzen, I. (1991). The theory of planned behavior. Journal of Organizational Behavior and Human Decision Processes, $50,179-211$.

Alvarez, M., Torres, A., Rodrigues, E., Padilla, S., \& Rodrigo, M. (2013). Attitudes and parenting dimensions in parents' regulation of internet use by primary and secondary school children. Journal of Computers \& Education, 67, 69-78.

Al-Debei, M., Al-Lozi, E., \& Papazafeiropoulou, A. (2013). Why people keep coming back to Facebook: Explaining and predicting continuance participation from an extended theory of planned behavior perspective. Journal of Decision Support Systems, 55(1), 43-54.

APJII. (2015). Profil Pengguna Internet Indonesia 2014 [Indonesian internet users profile 2014]. Retrieved March 21, 2016, from http://puskakomui.or.id/publikasi/rilis-pers-hasil-survey-profil-pengguna-internetdi-indonesia-2014-oleh-apjii-bekerja-sama-dengan-pusat-kajian-komunikasi-universitas-indonesia.html

Barbovschi, M., Macháčková, H., \& Ólafsson, M. (2015). underage use of social network sites: It's about friends. Journal of Cyberpsychology, Behavior, and Social Networking, 18(6), 328-332.

Bassell, K. (2010). Social media and the implications for nursing faculty mentoring: A review of the literature. Journal of Teaching and Learning in Nursing, 5(4), 143-148.

Bollen, K. A. (1989). Structural equations with latent variables. New York: Wiley.

Chang, Y., \& Zhu, D. (2012). The role of perceived social capital and flow experience in building users' continuance intention to social networking sites in China. Journal of Computers in Human Behavior, 28(3), 995-1001.

Clifton, A., Goodall, D., Ban, S., \& Birks, E. (2013). New perspectives on the contribution of digital technology and social media use to improve the mental wellbeing of children and young people: A State-of-the-art review. Journal of Neonatal, Paediatric, and Child Health Nursing, 16(1), 19-26.

Cohen, J. (1988). Statistical power analysis for the behavioral sciences (2nd ed.). New Jersey: Lawrence Erlbaum Associates.

Cohen, J., \& Cohen, P. (1983). Applied multiple regression / Correlation analysis for the behavioral sciences (2nd ed.). New Jersey: Lawrence Erlbaum Associates. 
Davis, F. (1989). Perceived usefulness, perceived ease of use, and user acceptance of information technology. Information Systems Journal, 13, 319-340.

Davis, F., Bagozzi, R., \& Warshaw, P. (1989). User acceptance of computer technology: A comparison of two theoretical models. Journal of Management Science, 35(8), 982-1003.

Davis, F., Bagozzi, R., \& Warshaw, P. (1992). Extrinsic and intrinsic motivation to use computers in the workplace. Journal of Applied Social Psychology, 22(14), 1111-1132.

De-Miguel-Molina, M., Oltra-Gutiérrez, J., \& Sarabdeen, J. (2010). An exploratory study on the privacy of children's images in Spain's most widely used social network sites (Tuenti and Facebook). Journal of International Review of Law, Computers \& Technology, 24(3), 277-285.

Endestad, T., Heim, J., Kaare, B., Torgersen, L., \& Brandtzaeg, P. (2011). Media user types among young children and social displacement. Journal of Nordicom Review, 32(1), 17-30.

Erlin, Fitri, T. A., \& Susandri. (2015). Using social networks: Facebook usage at the Riau College Students. Journal of Procedia Computer Science, 59(2015), 559-566.

Ernst, C., Pfeiffer, J., \& Rothlauf, F. (2013). Hedonic and utilitarian motivations of social network site adoption. Mainz, Germany: Johannes Gutenberg University, Working Papers in Information Systems and Business Administration.

Gao, L., \& Bai, X. (2014). An empirical study on continuance intention of mobile social networking services Integrating the IS success model, network externalities and flow theory. Asia Pacific Journal of Marketing and Logistics, 26(2), 168-189.

Gazali, E. (2014). Learning by clicking: An experiment with social media democracy in Indonesia. Journal of International Communication Gazette, 76(4-5), 425-439.

George, D., \& Mallery, P. (2003). SPSS for Windows step by step: A simple guide and reference. 11.0 update. Boston: Allyn and Bacon.

Guarnacci, U. (2016). Joining the dots: Social networks and community resilience in post-conflict, post-disaster Indonesia. International Journal of Disaster Risk Reduction, 16, 180-191.

Hamm, M., Shulhan, J., Williams, G., Milne, A., Scott, S., \& Hartling, L. (2014). A systematic review of the use and effectiveness of social media in child health. Journal of BMC Pediatrics, 14(1), 138-153.

Hofstede, G. (1990). Cultural dimensions. Retrieved March 21, 2016, from www.geert-hofstede.com

Hong, J., Hwang, M., Ting, T., Tai, K., \& Lee, C. (2013). The innovativeness and self-efficacy predict the acceptance of using iPad 2 as a green behavior by the government's top administrators. The Turkish Online Journal of Educational Technology, 12(2), 313-320.

Hsiao, K. (2011). Why internet users are willing to pay for social networking services. Journal of Online Information Review, 35(5), 770-788.

Hsu, C., \& Lu, H. (2004). Why do people play online games? An extended TAM with social influences and flow experience. Journal of Information \& Management, 41, 853-868.

Israel, G. D. (2013). Determining sample size. Retrieved December 20, 2014, from https://edis.ifas.ufl.edu/pd006

Karuppiah, N. (2014). Computer habits and behaviors among young children in Singapore. Journal of Early Child Development and Care, 185(3), 393-408.

Kline, R. B. (2005). Principles and practice of structural equation modeling. London: Guilford Press.

KomInfo. (2014). Pengguna Internet di Indonesia Capai 82 Juta [Indonesian internet users reach 82 million]. Retrieved March 21, 2016, from http:// kominfo.go.id/index.php/content/detail/3980/Kemkominfo $\% 3 \mathrm{~A}+$ Pengguna+Internet+di+Indon esia+Capai+82+Juta/0/berita satker\#.Vj27mrcrLIV

Ku, Y., Chen, R., \& Zhang, H., (2013). Why do users continue using social networking sites? An exploratory study of members in the United States and Taiwan. Information \& Management Journal, 50(7), 571-581. 
Kwon, O., \& Wen, Y. (2010). An empirical study of the factors affecting social network service use. Journal of Computers in Human Behavior, 26(2), 254-263.

Lee, K. (2015). Your 9-year-old child: Cognitive development. Retrieved March 21, 2016, from http://childparenting.about.com/od/schoollearning/a/Your-9-Year-Old-Child-CognitiveDevelopment.htm

Lewis, M. (2005). The child and its family: The social network model. Human Development, 48(1-2), 8-27.

Lim, M. (2013). Many clicks but little sticks: Social media activism in Indonesia. Journal of Contemporary Asia, 43(4), 636-657.

Livingstone, S. (2014). Developing social media literacy: How children learn to interpret risky opportunities on social network sites. Journal of Communications, 39(3), 283-303.

Lourenco, F., Decker, J., Pedersen, G., Dellarco, D., Casey, B., \& Hartley, C. (2015). Consider the source: Adolescents and adults similarly follow older adult advice more than peer advice. Plos One. DOI: 10.1371/journal.pone.0128047

Lwin, M., Miyazaki, A., Stanaland, A., \& Lee, E. (2012). Online usage motive and information disclosure for preteen children. Journal of Young Consumers, 13(4), 345-356.

Maharani, W., \& Gozali, A. (2015). Collaborative social network analysis and content-based approach to improve the marketing strategy of SMEs in Indonesia. Journal of Procedia Computer Science, 59(2015), 373-381.

Neuman, W. L. (2006). Social research methods, qualitative and quantitative approaches (6th ed.). Boston: Allyn and Bacon.

Park, C., \& Lee, J. (2012). Factors influencing the accessibility of online social game. IEEE Symposium on ELearning, E-Management, and E-Services (pp.1-4). Kuala Lumpur, Malaysia: Grand Seasons Hotel.

Praveena, K., \& Thomas, S. (2013). Continuance intention to use Facebook: Role of perceived enjoyment and trust. the International Journal of Business \& Management, 1(6), 26-32.

Predrag, K. (2014). Engagement factors in social media experience. $1^{\text {st }}$ International Scientific Conference on ICT and E-Business related Research (209-212). Belgrade: Singidunum University.

Pruet, P., Ang, C., \& Farzin, D. (2014). Understanding tablet computer usage among primary school students in underdeveloped areas: Students' technology experience, learning styles and attitudes. Journal of Computers in Human Behavior, 55, 1131-1144.

Renny, Guritno, S., \& Siringoringo, H. (2013). Perceived usefulness, ease of use, and attitude towards online shopping usefulness towards online airlines ticket purchase. Procedia - Social and Behavioral Sciences, 81:212216.

Shen, A., Cheung, C., Lee, M., \& Chen, H. (2011). How social influence affects we-intention to use instant messaging: The moderating effect of usage experience. Journal of Information Systems Frontiers, 13(2), 157169.

Shin, D., \& Shin, Y. (2011). Why do people play social network games?. Journal of Computers in Human Behavior, $27(2), 852-861$.

Shin, W., \& Ismail, N. (2014). Exploring the role of parents and peers in young adolescents' risk taking on social networking sites. Journal of Cyber Psychology, Behavior, and Social Networking, 17(9), 578-583.

Sobel, M. E. (1986). Sociological methodology. San Francisco: Jossey-Bass.

Staksrud, E., Olafsson, K., \& Livingstone, S. (2013). Does the Use of Social Networking Sites Increase Children's Risk of Harm? Journal of Computers in Human Behavior, 29(1), 40-50.

Straub, D., Boudreau, M-C., \& Gefen, D. (2004). Validation guidelines for IS positivist research. Communications of the Association of Information Systems, 13, 380-427.

TechInAsia. (2016). The latest stats in web and mobile in Indonesia (INFOGRAPHIC). Retrieved March 21, 2016, from https://www.techinasia.com/indonesia-web-mobile-statistics-we-are-social 
Factors Affecting Social Network Use by Students in Indonesia

Wang, J., Jackson, L., Gaskin, J., \& Wang, H. (2014). The effects of social network site (SNS) use on college students' friendship and well-being. Journal of Computers in Human Behavior, 37, 229-236.

Wang, T., \& Tseng, Y. (2011). A study of the effect on trust and attitude with online shopping. International Journal of Digital Society, 2(2), 433-440.

Youn, S. (2008). Parental influence and teens' attitude toward online privacy protection. Journal of Consumer Affairs, 42(3), 362-388.

YourDictionary, (2015). Risk. Retrieved March 21, 2016, from http://www.yourdictionary.com/risk

Zhang, C. (2010). Technology acceptance in learning settings from a student perspective: A theoretical framework. ACM Conference on Information Tecbnology Education (37-41). Midland, MI: Central Michigan University. 


\section{APPENDIX A. NOTATED QUESTIONNAIRE}

The questionnaire has been abbreviated and shows labels for variables/indicators and their measurement scales.

\section{Section 1}

1. Your age (AGE): ... years old 2. Gender (GENDER): $\square$ male (1) $\square$ female (2)

3. Type of SNS that you use regularly (TYPE): $\square$ Facebook (1) $\square$ BBM (2) $\square$ Line (3) Twitter (4) $\square$ Youtube (5) $\square$ Other: (6) 4. Number of hours each day you use SNS: (HOURS) ......hours

5. The platform you use to access SNS (PLAT): $\square$ Android (1) $\square$ IOS (2) $\square$ Blackberry (3) Windows (4) $\square$ Other: (AC) ......

\section{Section 2}

Responses to each statement were on 5-point scales: Strongly Disagree (1), Disagree (2), Not Decided (3), Agree (4), Strongly Agree (5).

\begin{tabular}{|l|l|}
\hline Flow Experience (FE1 - FE3) & $\begin{array}{l}\text { My friends tell me not to do particular acts } \\
\text { through SNS. }\end{array}$ \\
\hline I feel time passes quickly while using SNS. & $\begin{array}{l}\text { My friends complain when I do something } \\
\text { through SNS that they don't like. }\end{array}$ \\
\hline I never think of other things while using SNS. & Perceived Parent Influence (PPaI1 - PPaI3) \\
\hline When using SNS, I found a lot of pleasure. & My parents want to know what I do with SNS. \\
\hline Technology Self-Efficacy (TSE1 - TSE3) & $\begin{array}{l}\text { My parents tell me not to do particular acts } \\
\text { through SNS. }\end{array}$ \\
\hline $\begin{array}{l}\text { I can use SNS without any difficulty even when no one has } \\
\text { taught me how to use it. }\end{array}$ & $\begin{array}{l}\text { My parents complain when I do something } \\
\text { through SNS that they don't like. }\end{array}$ \\
\hline $\begin{array}{l}\text { I can use SNS without looking at the user manual as a ref- } \\
\text { erence. }\end{array}$ & Risk (R1 - R3) \\
\hline $\begin{array}{l}\text { I have the confidence to use SNS if someone demonstrates } \\
\text { the operating methods briefly for me once. }\end{array}$ & I do not believe that SNS is a secure system. \\
\hline Perceived Ease of Use (PEU1 - PEU3) & $\begin{array}{l}\text { I do not believe the SNS provider's promises and } \\
\text { commitments. }\end{array}$ \\
\hline It is easy for me to become skillful at using SNS. & $\begin{array}{l}\text { I do not believe that chatting, uploading, and } \\
\text { downloading images on SNS is secure. }\end{array}$ \\
\hline SNS features are easy to use. & Technology Accessibility (TA1 - TA3) \\
\hline I find it is easy to use SNS. & I can connect with friends on SNS anytime. \\
\hline Perceived Usefulness (PU1 - PU3) & I can use SNS with various devices. \\
\hline Overall, SNS is useful for me. & I can access SNS from any place. \\
\hline SNS benefits me. & Technology Experience (TE1 - TE3) \\
\hline SNS is useful for the things that I want to do. & I have used SNS before. \\
\hline Perceived Enjoyment (PE1 - PE3) & I have devices to enable me to use SNS. \\
\hline I have fun using SNS. & $\begin{array}{l}\text { I have internet connection to be able to access } \\
\text { SNS. }\end{array}$ \\
\hline Using SNS is pleasant. & $\begin{array}{l}\text { Attitude toward Use of Technology (AUT1 - } \\
\text { AUT3) }\end{array}$ \\
\hline I find using SNS to be enjoyable. & I have positive feelings towards SNS in general. \\
\hline Perceived Peer Influence (PPeI1 - PPeI3) & Using SNS appeals to me. \\
\hline My friends want to know what I do with SNS. & I think that it is a good idea for me to use SNS. \\
\hline
\end{tabular}


Factors Affecting Social Network Use by Students in Indonesia

Table A1: Factor analysis of construct validity and Cronbach alpha coefficients

\begin{tabular}{|c|c|c|c|c|c|c|c|c|c|c|c|}
\hline \multirow[b]{2}{*}{ 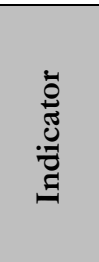 } & \multicolumn{10}{|c|}{ Latent Variable } & \multirow[b]{2}{*}{$\begin{array}{l}\text { Cronbach } \\
\text { Alpha } \\
\text { Coefficient }\end{array}$} \\
\hline & $\frac{\vec{n}}{\vec{n}}$ & 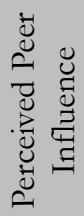 & 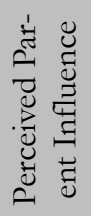 & 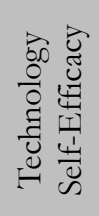 & 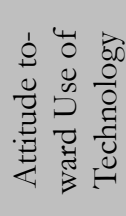 & 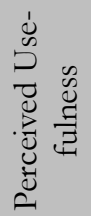 & 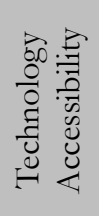 & 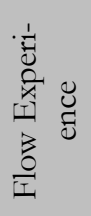 & 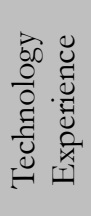 & 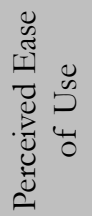 & \\
\hline R2 & .912 & .023 & -.076 & .039 & .088 & .100 & .049 & .051 & -.012 & .074 & \multirow{3}{*}{$\begin{array}{c}.926 \\
\text { Excellent }\end{array}$} \\
\hline R1 & .895 & $\begin{array}{c}- \\
.024\end{array}$ & -.167 & .062 & .130 & .134 & .077 & .002 & -.003 & .068 & \\
\hline R3 & .891 & .015 & -.119 & .060 & .142 & .140 & .096 & .025 & .005 & .097 & \\
\hline PPeI3 & .000 & .934 & .149 & -.036 & -.006 & .037 & -.016 & .043 & .018 & -.023 & \multirow{3}{*}{$\begin{array}{c}.930 \\
\text { Excellent }\end{array}$} \\
\hline PPeI1 & .049 & .930 & .070 & .002 & .059 & .042 & -.007 & -.023 & .036 & -.003 & \\
\hline PPeI2 & -.037 & .914 & .183 & -.051 & -.041 & $\begin{array}{c}- \\
.050 \\
\end{array}$ & .007 & .029 & .047 & -.047 & \\
\hline PPaI1 & -.043 & 1119 & .914 & -.014 & -.027 &. & .002 & .042 & .018 & -.017 & \multirow{3}{*}{$\begin{array}{c}.927 \\
\text { Excellent }\end{array}$} \\
\hline PPaI2 & -.151 & .141 & .914 & .015 & -.069 &.- & -.032 & -.011 & .060 & -.014 & \\
\hline PPaI3 & -.156 & .150 & .913 & .019 & -.035 &. & -.038 & .014 & .038 & -.048 & \\
\hline TSE2 & .045 & $\begin{array}{c}- \\
.031\end{array}$ & .002 & .885 & .087 & .088 & .153 & .084 & .107 & .174 & \multirow{3}{*}{$\begin{array}{c}.908 \\
\text { Excellent }\end{array}$} \\
\hline TSE1 & .045 & .000 & -.043 & .862 & .052 & .033 & .134 & .118 & .139 & .245 & \\
\hline TSE3 & .075 & $\begin{array}{c}- \\
.061\end{array}$ & .057 & .855 & .126 & .072 & .089 & .122 & .117 & .159 & \\
\hline AUT2 & .147 & .036 & -.042 & .094 & .853 & 188 & .102 & .125 & .050 & .183 & \multirow{3}{*}{$\begin{array}{c}.894 \\
\text { Good }\end{array}$} \\
\hline AUT1 & .172 &. & -.043 & .078 & .838 & .146 & .111 & .148 & .151 & .186 & \\
\hline AUT3 & .073 & $\begin{array}{c}- \\
.007\end{array}$ & -.061 & .104 & .823 & .175 & .183 & .172 & .060 & .053 & \\
\hline PU1 & .135 & .048 & -.067 & .058 & .184 & .828 & .152 & .116 & .113 & .069 & \multirow{3}{*}{$\begin{array}{l}.863 \\
\text { Good }\end{array}$} \\
\hline PU3 & .111 & $\begin{array}{c}- \\
.016\end{array}$ & -.015 & .064 & .150 & .826 & .117 & .082 & .097 & .157 & \\
\hline PU2 & .140 & .005 & -.071 & .072 & .155 & .819 & .154 & .058 & .116 & .136 & \\
\hline TA3 & .069 &. & -.038 & .143 & .106 & .196 & .836 & .106 & .168 & .092 & \multirow{3}{*}{$\begin{array}{c}.857 \\
\text { Good }\end{array}$} \\
\hline TA1 & .045 & .027 & -.025 & .099 & .134 & .122 & .819 & .122 & .099 & .197 & \\
\hline TA2 & .113 &. & -.008 & .131 & .139 & .107 & .792 & .078 & .183 & .148 & \\
\hline FE2 & .103 & .012 & .047 & .049 & .106 & .076 & .073 & .870 & .035 & .110 & \multirow{3}{*}{$\begin{array}{l}.843 \\
\text { Good }\end{array}$} \\
\hline FE1 & -.078 & .070 & .024 & .143 & .082 & .022 & .104 & .862 & .084 & .044 & \\
\hline FE3 & .051 & .039 & -.028 & .108 & .225 & .152 & .108 & .774 & .104 & .166 & \\
\hline TE1 & .009 & .038 & .014 & .094 & .037 & .025 & .144 & .058 & .859 & .076 & \multirow{3}{*}{$\begin{array}{c}.834 \\
\text { Good }\end{array}$} \\
\hline TE2 & -.027 & .004 & .081 & .136 & .077 & .161 & .105 & .067 & .845 & .116 & \\
\hline TE3 & .002 & .064 & .025 & .105 & .119 & .126 & .162 & .093 & .775 & .127 & \\
\hline PEU2 & .115. & $\begin{array}{c}- \\
.021 \\
\end{array}$ & $\begin{array}{l}.083 \\
\end{array}$ & .150 & .116 & $\begin{array}{l}.149 \\
\end{array}$ & .169 & .118 & .060 & .822 & \multirow{3}{*}{$\begin{array}{l}.840 \\
\text { Good }\end{array}$} \\
\hline PEU3 & .073 & $\begin{array}{c}- \\
.057 \\
\end{array}$ & -.038 & .207 & .148 & .128 & .130 & .116 & .168 & .803 & \\
\hline PEU1 & .062 & $\begin{array}{c}- \\
.007\end{array}$ & .034 & .237 & .141 & .095 & .146 & .106 & .126 & .745 & \\
\hline
\end{tabular}




\begin{tabular}{|c|c|c|c|c|c|c|}
\hline \multicolumn{7}{|c|}{ Variance Explained } \\
\hline \multirow[b]{2}{*}{ Latent Variable } & \multicolumn{3}{|c|}{ Initial Eigenvalues } & \multicolumn{3}{|c|}{ Rotation Sums of Squared Loadings } \\
\hline & Total & $\begin{array}{c}\text { Percent } \\
\text { of Vari- } \\
\text { ance }\end{array}$ & $\begin{array}{c}\text { Cumulative } \\
\text { Percent }\end{array}$ & Total & $\begin{array}{l}\text { Percent of } \\
\text { Variance }\end{array}$ & $\begin{array}{c}\text { Cumulative } \\
\text { Percent }\end{array}$ \\
\hline Risk & 7.756 & 25.852 & 25.852 & 2.658 & 8.861 & 8.861 \\
\hline Perceived Peer Influence & 3.698 & 12.327 & 38.179 & 2.657 & 8.857 & 17.718 \\
\hline $\begin{array}{l}\text { Perceived Parent Influ- } \\
\text { ence }\end{array}$ & 2.678 & 8.927 & 47.106 & 2.656 & 8.852 & 26.571 \\
\hline Technology Self-Efficacy & 1.885 & 6.282 & 53.388 & 2.550 & 8.499 & 35.070 \\
\hline $\begin{array}{l}\text { Attitude toward Use of } \\
\text { Technology }\end{array}$ & 1.855 & 6.184 & 59.572 & 2.465 & 8.216 & 43.286 \\
\hline Perceived Usefulness & 1.627 & 5.422 & 64.994 & 2.387 & 7.956 & 51.242 \\
\hline Technology Accessibility & 1.379 & 4.598 & 69.592 & 2.336 & 7.786 & 59.028 \\
\hline Flow Experience & 1.327 & 4.424 & 74.016 & 2.321 & 7.737 & 66.765 \\
\hline Technology Experience & 1.265 & 4.215 & 78.231 & 2.310 & 7.700 & 74.465 \\
\hline Perceived Ease of Use & 1.152 & 3.840 & 82.071 & 2.282 & 7.606 & 82.071 \\
\hline \multicolumn{7}{|c|}{$\begin{array}{l}\text { Extraction Method: Principal Component Analysis. Rotation Method: Equamax with Kaiser Normalization. } \\
\text { Rotation converged in } 7 \text { iterations. Kaiser-Meyer-Olkin Measure of Sampling Adequacy .850. Bartlett's Test of } \\
\text { Sphericity: Approx. Chi-Square 9302.850; Degrees of freedom 435; Significance } 0.000 \text {. Only eigenvalues of } 1 \\
\text { or more are shown. }\end{array}$} \\
\hline
\end{tabular}

Notes: (a) Satisfactory construct validity requires the magnitude of factor loadings to be at least 0.4 and the associated eigenvalue to be at least 1 (Straub, Boudreau, \& Gefen, 2004); (b) Cronbach alpha coefficients $\geq 0.9$ (excellent) and $0.8 \leq$ Alpha coefficients $<0.9$ (good) (George \& Mallery, 2003).

Table A2: Descriptive statistics for model variables

\begin{tabular}{|c|c|c|c|c|c|c|c|c|c|}
\hline Variable/Indicator & $\sum_{\Sigma}^{\varpi ๊}$ & 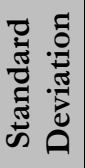 & 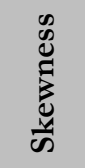 & 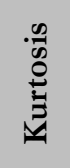 & Variable/Indicator & $\sum_{\Sigma}^{\tilde{\Sigma}}$ & 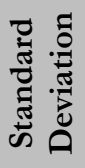 & 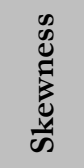 & $\begin{array}{l}\frac{n}{0} \\
\stackrel{0}{0} \\
\frac{0}{2} \\
4\end{array}$ \\
\hline Flow Experience & 4.07 & .81 & -1.02 & .62 & Perceived Parent Influence & 3.90 & 1.01 & -1.19 & .84 \\
\hline FE1 & 4.10 & .82 & -.89 & .60 & PPaI1 & 3.90 & 1.00 & -.92 & .42 \\
\hline FE2 & 3.90 & .83 & -.67 & .12 & PPaI2 & 3.90 & 1.13 & -1.10 & .63 \\
\hline FE3 & 4.19 & .82 & -.57 & -.37 & $\mathrm{PPaI} 3$ & 3.88 & 1.13 & -1.02 & .40 \\
\hline $\begin{array}{l}\text { Technology Self- } \\
\text { Efficacy }\end{array}$ & 3.79 & 1.03 & -.84 & .00 & Risk & 2.70 & .98 & .37 & -.31 \\
\hline TSE1 & 3.84 & 1.04 & -.70 & -.21 & R1 & 2.30 & .98 & .31 & -.31 \\
\hline TSE2 & 3.68 & 1.08 & -.62 & -.41 & R2 & 3.36 & .96 & .24 & -.37 \\
\hline TSE3 & 3.86 & 1.06 & -.72 & .33 & R3 & 3.23 & .97 & .30 & -.32 \\
\hline $\begin{array}{l}\text { Perceived Ease of } \\
\text { Use }\end{array}$ & 4.13 & .76 & -.76 & .37 & Technology Accessibility & 3.99 & .78 & -.64 & .16 \\
\hline PEU1 & 4.17 & .77 & -.57 & .04 & TA1 & 4.11 & .79 & -.73 & .28 \\
\hline PEU2 & 4.09 & .78 & -.65 & .15 & TA2 & 3.95 & .79 & -.45 & -.12 \\
\hline PEU3 & 4.14 & .78 & -.64 & -.04 & TA3 & 3.92 & .78 & -.46 & -.27 \\
\hline Perceived Usefulness & 3.91 & .84 & -.51 & -.26 & Technology Experience & 4.17 & .65 & -.19 & -.48 \\
\hline PU1 & 3.94 & .84 & -.46 & -.38 & TE1 & 4.16 & .65 & -.07 & -.33 \\
\hline PU2 & 3.83 & .83 & -.36 & -.38 & TE2 & 4.12 & .64 & -.11 & -.60 \\
\hline PU3 & 3.95 & .83 & -.50 & -.25 & TE3 & 4.23 & .65 & -.26 & -.71 \\
\hline $\begin{array}{l}\text { Perceived Peer Influ- } \\
\text { ence }\end{array}$ & 3.13 & 1.10 & -.28 & -.85 & $\begin{array}{l}\text { Attitude toward Use of } \\
\text { Technology }\end{array}$ & 4.00 & .83 & -.66 & .10 \\
\hline PPeI1 & 3.21 & 1.08 & -.20 & -.73 & AUT1 & 4.08 & .84 & -.53 & -.52 \\
\hline PPeI2 & 3.07 & 1.07 & -.15 & -.89 & AUT2 & 4.10 & .82 & -.66 & -.12 \\
\hline PPeI3 & 3.10 & 1.06 & -.23 & -.87 & AUT3 & 3.82 & .84 & -.50 & .16 \\
\hline
\end{tabular}


Table A3: Correlation among model variables

\begin{tabular}{|c|c|c|c|c|c|c|c|c|c|}
\hline Model Variable & FE & TSE & PEU & PU & PPeI & PPaI & $\mathbf{R}$ & TA & TE \\
\hline Technology Self-Efficacy (TSE) & .291 & 1 & & & & & & & \\
\hline Perceived Ease of Use (PEU) & .328 & .491 & 1 & & & & & & \\
\hline Perceived Usefulness (PU) & .263 & .237 & .374 & 1 & & & & & \\
\hline Perceived Peer Influence (PPeI) & .035 & -.059 & -.061 & .014 & 1 & & & & \\
\hline Perceived Parent Influence (PPaI) & .017 & -.011 & -.086 & -.128 & .288 & 1 & & & \\
\hline Risk (R) & -.111 & -.163 & -.244 & -.326 & -.015 & .265 & 1 & & \\
\hline Technology Accessibility (TA) & .300 & .361 & .430 & .402 & -.016 & -.072 & $\begin{array}{c}- \\
.224\end{array}$ & 1 & \\
\hline Technology Experience (TE) & .233 & .320 & .336 & .303 & .075 & .077 & $\begin{array}{c}- \\
.046\end{array}$ & .386 & 1 \\
\hline Attitude toward Use of Technology (AUT) & .373 & .288 & .406 & .447 & .001 & -.123 & $\begin{array}{c}- \\
.323\end{array}$ & .385 & .263 \\
\hline
\end{tabular}

Notes: (a) Coefficients in bold type are statistically significant at a level of 0.05 or less; (b) Shaded cells identify correlation coefficients associated with causal effects in the modified theoretical model in Figure 2.

\section{APPENDix B. Model Fit Statistics}

Table B1 summarizes the interpretation of the range of model fit statistics recommended by Kline (2005) for assessing causal models.

Table B1: Interpretation of model fit statistics

\begin{tabular}{|l|l|}
\hline \multicolumn{1}{|c|}{ Model Fit Statistics } & \multicolumn{1}{c|}{ Interpretations } \\
\hline Model Chi-Square $\chi^{2}$ & Small values of $\chi^{2}$ with $\mathrm{p}>0.05$ indicate at least a reasonable fit. \\
\hline $\begin{array}{l}\chi^{2} / \mathrm{df} \text { (Normed Chi-square, } \\
\text { fC) where df is the degrees of } \\
\text { freedom }\end{array}$ & $\begin{array}{l}\text { Values of } 0<\mathrm{NC}<5 \text { are considered to indicate at least a reasonable model } \\
\text { fit. }\end{array}$ \\
\hline $\begin{array}{l}\text { RMR (Root Mean Square Resid- } \\
\text { ual) }\end{array}$ & $\begin{array}{l}\text { RMR values close to } 0 \text { indicate a good model fit. The fit gets worse as the } \\
\text { value of RMR increases. }\end{array}$ \\
\hline $\begin{array}{l}\text { GFI (Goodness of Fit Index) } \\
\text { AGFI (Adjusted GFI) }\end{array}$ & $\begin{array}{l}\text { GFI }=1 \text { means a perfect fit, GFI }>0.9 \text { means a good fit, GFI }=0 \text { indicates a } \\
\text { poor fit. AGFI corrects GFI downward based on model complexity }\end{array}$ \\
\hline $\begin{array}{l}\text { NFI (Normed Fit Index) } \\
\text { IFI (Incremental Fit Index) } \\
\text { CFI (Comparative Fit Index) }\end{array}$ & NFI, IFI, CFI should have values $>0.9$ to indicate a good model fit. \\
\hline $\begin{array}{l}\text { RMSEA (Root Mean Square } \\
\text { Error of Approximation) }\end{array}$ & $\begin{array}{l}\text { RMSEA less than or equal to } 0.05 \text { means a close fit; between } 0.05 \text { and } 0.08 \\
\text { means a reasonable fit, } 0.1 \text { or more indicates a poor fit. }\end{array}$ \\
\hline
\end{tabular}

Following suggestions by Kline (2005) the value of $\chi^{2} / \mathrm{df}$ (Normed Chi-square, NC) rather than $\chi^{2}$ is recommended to select appropriate models because: the hypothesis tested by $\chi^{2}$ that a model has a perfect population fit is implausible; $\chi^{2}$ is sensitive to the size of correlations and larger correlations generally lead to higher values of $\chi^{2}$; and $\chi^{2}$ is affected by sample size $(N)$ so that if the sample size is large, which is required in order to interpret the index as a test statistic, the value of $\chi^{2}$ may lead to the rejection of the model even though differences between observed and predicted covariances are slight. To reduce the sensitivity of $\chi^{2}$ to sample size $\mathrm{NC}$ is used commonly and despite no clear cut guideline about what value of $\mathrm{NC}$ is minimally acceptable Bollen (1989) notes that values of NC of 2,3 , or even as high as 5 have been recommended as indicating reasonable fit. 


\section{APPENDix C. STATISTICAL SigNifiCANCE Of EFFECTS}

For unstandardized direct effects their statistical significance is reported routinely when using Amos software. However, for indirect effects, the total of indirect effects, and the total of all effects the statistical significance has to be determined by using special features of Amos or by using methods that are not implemented in Amos.

The statistical significance of the indirect effect of $\mathrm{X}$ on $\mathrm{Z}$ through the mediator (intervening variable) $\mathrm{Y}$ is found using the Sobel (1986) test, which states that:

If $a, b$ are the unstandardized coefficients for the paths $X$ to $Y$ and $Y$ to $Z$, respectively, then the standard error for the indirect effect of $X$ on $Z$ through $Y$ is estimated by $S E_{a b}=\sqrt{ }\left[\left(b S E_{a}\right)^{2}+\left(a S E_{b}\right)^{2}\right]$, where $S E_{a}$ and $S E_{b}$ are the standard errors for $a$ and $b$, respectively. Furthermore, for large samples $Z=a b / S E_{a b}$ is approximated by a standard normal distribution.

Determining the statistical significance of the indirect effect of $\mathrm{X}$ on $\mathrm{Z}$ through two or more mediators is an unresolved statistical problem (Kline 2005). However, a rule proposed by Cohen \& Cohen (1983) states that: If all the component unstandardized path coefficients are statistically significant at the same level of significance then the whole indirect effect is statistically significant at that level.

For the total of indirect effects and the total of all effects the method of nonparametric bootstrapping is available in Amos and is used with a selected number of random samples to estimate standard errors (SE) for these unstandardized totals. The SE is then used to test the statistical significance of these totals (Kline 2005).

\section{BIOGRAPHY}

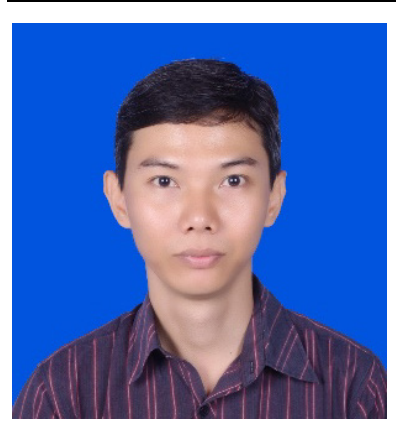

Budhi Kristianto is lecturer at the Faculty of Information Technology, Satya Wacana Christian University, Salatiga - Indonesia. He studies at Assumption University of Thailand and graduated from Chung Yuan Christian University, Taiwan. 